\title{
Fusarium as a Novel Fungus for the Synthesis of Nanoparticles: Mechanism and Applications
}

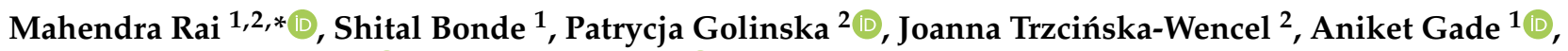 \\ Kamel A. Abd-Elsalam ${ }^{3}{ }^{\circ}$, Sudhir Shende ${ }^{1,4}{ }^{\mathbb{D}}$, Swapnil Gaikwad ${ }^{5}$ and Avinash P. Ingle ${ }^{6}$ \\ 1 Department of Biotechnology, Nanobiotechnology Laboratory, Sant Gadge Baba Amravati University, \\ Amravati 444602, India; shitalbonde@gmail.com (S.B.); aniketgade@gmail.com (A.G.); \\ sudhirsshende13884@gmail.com (S.S.) \\ 2 Department of Microbiology, Nicolaus Copernicus University, Lwowska, 87-100 Torun, Poland; \\ golinska@umk.pl (P.G.); trzcinska@doktorant.umk.pl (J.T.-W.) \\ 3 Agricultural Research Center, Plant Pathology Research Institute, Giza 12619, Egypt; \\ kamelabdelsalam@gmail.com \\ 4 Academy of Biology and Biotechnology, Southern Federal University, 344006 Rostov-on-Don, Russia \\ 5 Microbial Diversity Research Centre, Dr. D. Y. Patil Biotechnology and Bioinformatics Institute, Dr. D. Y. Patil \\ Vidyapeeth (Deemed to be University), Tathawade, Pune 411033, India; gaikwad.swapnil1@gmail.com \\ 6 Biotechnology Centre, Department of Agricultural Botany, Dr. Panjabrao Deshmukh Krishi Vidyapeeth, \\ Akola, Maharashtra 444104, India; Ingleavinash14@gmail.com \\ * Correspondence: mahendrarai7@gmail.com; Tel.: +91-779-8077-773
}

check for updates

Citation: Rai, M.; Bonde, S.;

Golinska, P.; Trzcińska-Wencel, J.;

Gade, A.; Abd-Elsalam, K.A.; Shende,

S.; Gaikwad, S.; Ingle, A.P. Fusarium as a Novel Fungus for the Synthesis of Nanoparticles: Mechanism and Applications. J. Fungi 2021, 7, 139. https://doi.org/10.3390/jof7020139

Academic Editor: Jeffrey J. Coleman Received: 14 December 2020

Accepted: 10 February 2021

Published: 15 February 2021

Publisher's Note: MDPI stays neutral with regard to jurisdictional claims in published maps and institutional affiliations.

Copyright: (c) 2021 by the authors. Licensee MDPI, Basel, Switzerland. This article is an open access article distributed under the terms and conditions of the Creative Commons Attribution (CC BY) license (https:// creativecommons.org/licenses/by/ $4.0 /)$.

\begin{abstract}
Nanotechnology is a new and developing branch that has revolutionized the world by its applications in various fields including medicine and agriculture. In nanotechnology, nanoparticles play an important role in diagnostics, drug delivery, and therapy. The synthesis of nanoparticles by fungi is a novel, cost-effective and eco-friendly approach. Among fungi, Fusarium spp. play an important role in the synthesis of nanoparticles and can be considered as a nanofactory for the fabrication of nanoparticles. The synthesis of silver nanoparticles (AgNPs) from Fusarium, its mechanism and applications are discussed in this review. The synthesis of nanoparticles from Fusarium is the biogenic and green approach. Fusaria are found to be a versatile biological system with the ability to synthesize nanoparticles extracellularly. Different species of Fusaria have the potential to synthesise nanoparticles. Among these, F. oxysporum has demonstrated a high potential for the synthesis of AgNPs. It is hypothesised that NADH-dependent nitrate reductase enzyme secreted by F. oxysporum is responsible for the reduction of aqueous silver ions into AgNPs. The toxicity of nanoparticles depends upon the shape, size, surface charge, and the concentration used. The nanoparticles synthesised by different species of Fusaria can be used in medicine and agriculture.
\end{abstract}

Keywords: Fusarium; synthesis; nanoparticles; mechanism; medicine; agriculture; nanofactory; toxicity

\section{Introduction}

Nanotechnology is an emerging branch of science having enormous applications in almost all fields related to human life. It is mainly concerned with the synthesis and applications of materials having a size in the range of 1 to 100 nanometers [1]. Nanomaterials possess exceptionally novel properties such as a high surface-area-to-volume ratio, high reactivity, enhanced catalytic and biological properties. All these unique properties make the nanomaterials appropriate for a variety of applications including in biomedicine and agriculture [2-4]. To date, a variety of nanomaterials have been developed and many more are currently under investigation to be applied in biomedicine with the emphasis on various life-threatening diseases including cancer. Therefore, some precious metals (like silver, gold and platinum) and some magnetic oxides (i.e., magnetite $\mathrm{Fe}_{3} \mathrm{O}_{4}$ ) nanoparticles received much attention [5]. Similarly, various nanoparticles have been reported to have 
many beneficial applications in agriculture which mainly include plant growth promotion, usage as nanofertilizer, and nanopesticides [6].

It is well demonstrated that various nanoparticles can be synthesized using physical, chemical, and biological methods [7]. The conventional physical and chemical methods used for the synthesis of nanoparticles usually involve the usage of toxic chemicals and also generate waste, which can cause environmental pollution [8,9]. However, the synthesis of biogenic nanoparticles using different biological agents such as plants, microbes, and their products has gained considerable attention worldwide due to the rapid synthesis and their eco-friendly nature compared to physical and chemical methods.

Among the biological agents, fungi have been preferably used for the synthesis of a variety of nanoparticles. Synthesis of nanoparticles using fungi is referred as mycosynthesis [10-13] and is being dealt with under myconanotechnology [14]. Gade et al. [15] stated the advantages of using filamentous fungi over other biological agents (e.g., bacteria) for the synthesis of nanoparticles. These mainly include high tolerance towards heavy metals, it is easy to culture fungi at mass level, synthesis of nanoparticles is extracellular which reduces the cost of down streaming, etc.

To date, several fungi have been successfully exploited for the biological synthesis of nanoparticles, but from the available literature, it is evident that different species of Fusarium are the prime choice for scientists. Various species of Fusarium such as Fusarium oxysporum, Fusarium semitectum, Fusarium acuminatum, Fusarium solani, Fusarium culmorum, etc. and their different strains [16-21] have been used for the synthesis of nanoparticles like silver, gold, platinum, silica, palladium, etc. Several other fungal species could also be employed in nanoparticle synthesis as described in Mahmoud et al. [22], Elamawi et al. [23], Noor et al. [24], and many more. Considering these facts, in the present review, we have discussed the importance of Fusarium for biosynthesis of nanoparticles. Moreover, various other key aspects such as the mechanism of nanoparticle synthesis from Fusarium and their applications in biomedicine and agriculture and toxicity have also been discussed.

\subsection{Diversity of Fusarium spp. for the Synthesis of Different Nanopartilces}

Fungi play a very important role in solving major global problems for sustainable development as compared to other biological systems. They enhance resource efficiency, converting waste to valuable food and feed ingredients, making crop plants more robust to survive in climate change conditions, and functioning as host organisms for the production of new biological drugs [25]. Fungi are the most promising hotspots for finding new drug candidates, metabolites, and antimicrobials [8]. They are also responsible for the shift from chemical processes to biological processing, achieved by fungal enzymes instead of chemical processes in industries, such as textiles, leather, paper, and pulp, which have significantly helped to make the process eco-friendly by reducing the negative impact on the environment $[16,26]$. The fungal system has been found to be a versatile biological system with the ability to synthesize metal nanoparticles intracellularly as well as extracellularly. Moreover, they are preferred over other biological systems because of their ubiquitous distribution in nature, and therefore, many fungi have been explored for the production of various metal nanoparticles of different shapes and size. Out of diverse fungal genera used for the synthesis of nanoparticles, the genus Fusarium has been the choice of many investigators $[13,16]$. The advantages of using Fusarium spp. for the synthesis of nanoparticles are enlisted in Figure 1. 


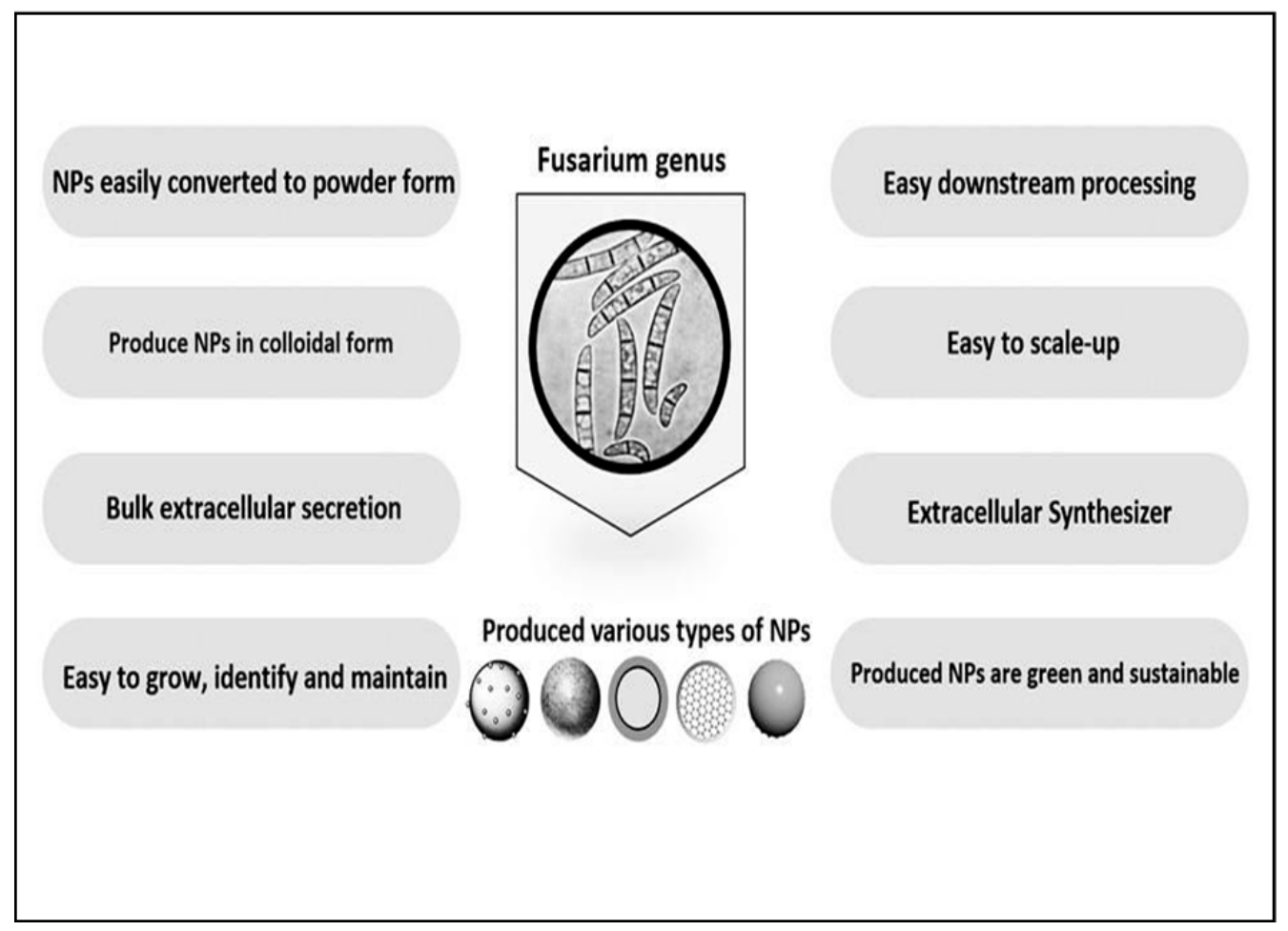

Figure 1. The advantages of using Fusarium spp. for the synthesis nanoparticles (NPs).

There are several reports on the synthesis of metal nanoparticles by different Fusarium spp. The exhaustive list of different Fusarium spp. involved with synthesis of different metal nanoparticles is given in Table 1.

Table 1. List of Fusarium spp. synthesizing metal Nanoparticles.

\begin{tabular}{|c|c|c|}
\hline Fusarium spp. & Type of Nanoparticles & Reference \\
\hline Fusarium acuminatum & Silver, & Ingle et al. [10] \\
\hline Fusarium solani & Silver & Ingle et al. [11] \\
\hline Fusarium semitectum & Silver & Basavaraja et al. [19] \\
\hline Fusarium acuminatum & Gold & Tidke et al. [27] \\
\hline Fusarium culmorum & Silver & Bawaskar et al. [28] \\
\hline Fusarium chlamydosporum NG30 & Silver & Khalil et al. [29] \\
\hline Fusarium equiseti, Fusarium tricinctum & Silver & Gaikwad et al. [30] \\
\hline Fusarium proliferatum & Silver & Gaikwad et al. [30] \\
\hline Eusarium koratonlacticum $41-2$ & Zinc oxide & Mohamed et al. [31] \\
\hline Fusarium keratoplasticum AI-3 & Silver & Mohamed et al. [32] \\
\hline Fusarium monoliforme & Silver & Gaikwad et al. [30] \\
\hline Fusarium oxysporum & $\begin{array}{c}\text { Silver, } \\
\text { Gold, } \\
\text { Lead and Cadmium Carbonate, } \\
\text { Strontium Carbonate, Cadmium Sulfide, } \\
\text { Silica and Titania, } \\
\text { Silica, Barium Titanate, } \\
\text { Zirconia } \\
\text { Platinum } \\
\text { Magnetite } \\
\text { CdSe Quantum dot } \\
\text { CdTe Quantum dot } \\
\text { Titanium oxide } \\
\text { Chitosan } \\
\text { Zinc Sulfide }\end{array}$ & $\begin{array}{c}\text { Birla et al. [33] } \\
\text { Bansod et al. [34] } \\
\text { Sanyal et al. [35] } \\
\text { Rautaray et al. [36] } \\
\text { Ahmad et al. [37] } \\
\text { Bansal et al. [38] } \\
\text { Bansal et al. [39] } \\
\text { Bansal et al. [40] } \\
\text { Gupta and Chundawat [41] } \\
\text { Bharde et al. [42] } \\
\text { Kumar et al. [43] } \\
\text { Senapati et al. [44] } \\
\text { Ganpathy and Siva [45] } \\
\text { Boruah and Dutta [46] } \\
\text { Mirzadeh et al. [47] }\end{array}$ \\
\hline
\end{tabular}


Table 1. Cont.

\begin{tabular}{ccc}
\hline Fusarium spp. & Type of Nanoparticles & Reference \\
\hline Fusarium oxysporum f. sp. cubense JT1 & Gold & Thakker et al. [48] \\
Fusarium oxysporum 405 & Silver & Rajput et al. [49] \\
Fusarium oxysporum f. sp. lycopersici & Platinum et al. [50] & Cardenas et al. [51] \\
Fusarium oxysporum PTCC 5115 & Cadmium Sulphide & Karbasian et al. [52] \\
Fusarium graminearum & Silver & Ajah et al. [53] \\
Fusarium scirpi & Silver & Rodríguez-Serrano et al. [54] \\
& Silver & Sawle et al. [55] \\
Fusarium semitectum & Gold and Gold-silver alloy & Madakka et al. [56] \\
& Silver & Abbas and Baker [57] \\
Fusarium semitectum (KSU-4) & Selenium & Mahmoud et al. [58] \\
Fusarium solani & Silver & Kavitha et al. [59] \\
Fusarium solani ATLOY-8 & Zirconium Oxide & Gold \\
Fusarium verticillioides & Silver & Mekkawy Mekkawy et al. [61] \\
\hline
\end{tabular}

\subsection{F. oxysporum as a Novel Organism for Synthesis of Nanoparticles}

Several fungi have been used for the biosynthesis of various nanoparticles as they exhibit many advantages over other biosystems. After directing to the mycosynthesis of nanoparticles especially from Fusarium, nanoparticles with better size and monodispersity could be achieved. Additionally, the extracellular production of enzymes has an added benefit in the downstream handling of biomass [62] as compared to other biosystems like bacteria and plants. Consequently, using these expedient properties of Fusarium, it could be comprehensively used for the rapid and eco-friendly biosynthesis of nanoparticles [53]. Gaikwad and colleagues [30] have screened eleven different Fusarium species isolated from various infected plant materials for the synthesis of silver nanoparticles (AgNPs). All the screened species revealed the ability for synthesis of AgNPs. Based on transmission electron microscopic (TEM) analysis, six Fusarium species—viz. F. graminearum, F. solani, F. oxysporum, F. culmorum, F. scirpi, F. tricinctum - synthesized smaller-sized particles, which signifies their prominence in AgNPs synthesis (Figure 2). Moreover, AgNPs synthesis from F. scirpi, F. graminearum, F. tricinctum was reported for the first time.

Khalil and coworkers [29] successfully synthesized and characterized AgNPs from F. chlamydosporum NG30 and P. chrysogenum NG85 which showed promising antifungal activity. The cellular mechanism of nanoparticle synthesis is yet to be completely understood; therefore, researchers have been trying to understand the mechanism at the cellular and molecular level [63]. They have reported the synthesis of gold nanoparticles (AuNPs) using F. oxysporum f. sp. cubense JT1 in $60 \mathrm{~min}$. Naimi-Shamel et al. [64] also proved that F. oxysporum has benefits like fast growth rate, low-cost biomass management, safety and easy processing for synthesis of AuNPs. AuNPs synthesized from F. oxysporum are found to have a high tendency of conjugation with $\beta$-Lactam antibiotics, and this affinity makes them a better detoxification agent as well in various areas including medicine [65]. An endophytic strain of $F$. solani isolated from Chonemorpha fragrans plant was used to synthesise nanoparticles with anticancer activity [60]. El-Sayed and El-Sayed [66] synthesized silver, copper and zinc biocidal nanoparticles from $F$. solani to combat multidrug-resistant pathogens. F. oxysporum-mediated AgNPs surface coated with different proteins and biomolecules act as a potential antimicrobial agent and proved by protein-ligand interaction in silico studies [66]. In another study by Birla et al., F. oxysporum produced more protein at an optimized temperature between $60^{\circ}$ and $80^{\circ} \mathrm{C}$ which showed the progressive increase in the rate of nanoparticle synthesis [33]. 

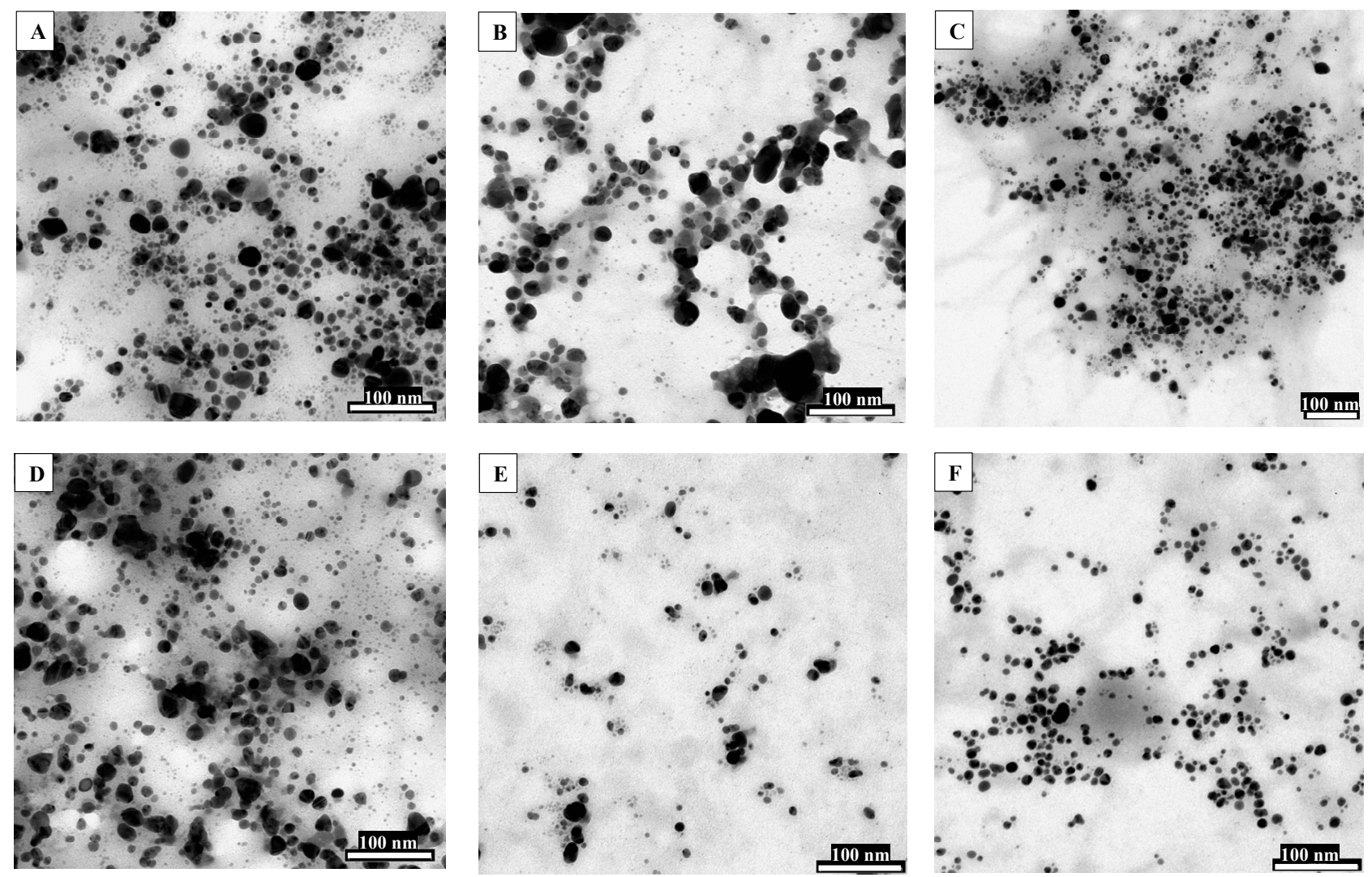

Figure 2. TEM micrographs presenting sphere-shaped AgNPs synthesized by various Fusarium species. (A) F. graminearum; (B) F. solani; (C) F. oxysporum; (D) F. culmorum; (E) F. scirpi; (F) F. tricinctum. (Reproduced with permission from Gaikwad et al. [30]).

\section{Mechanism of Nanoparticle Synthesis from Fusarium}

As discussed earlier, members of the genus Fusarium can synthesize metal nanoparticles both intracellularly and extracellularly. As far as the mechanism of extracellular mycosynthesis is concerned, it is proposed that metabolites such as enzymes, proteins, polysaccharides, flavonoids, alkaloids, phenolic and organic acids, etc. secreted by funguslike Fusarium for their survival when exposed to different environmental stresses are mostly responsible for the reduction of metals ions to metallic nanoparticles through the catalytic effect [67]. Moreover, the same metabolites act as reducing and stabilizing agents which are further responsible for the growth and stabilization of biogenic metal nanoparticles [13,22]. Figure 3 represents the schematic illustration of the general mechanism involved in the synthesis, growth, and stabilization of metal nanoparticles using fungus such as Fusarium.

One of the hypothetical mechanisms proposed is that NADH-dependent nitrate reductase enzyme secreted by F. oxysporum is responsible for the reduction of aqueous silver ions into AgNPs [16]. A similar mechanism has been proposed by Ingle et al. [10] in case of synthesis of AgNPs from F. acuminatum, and they also pointed the involvement of cofactor NADH and nitrate reductase enzyme in the biosynthesis of AgNPs because they reported the presence of nitrate reductase in fungal cell-free extract using specific substrate utilizing discs for nitrate purchased from Hi-Media Pvt. Ltd. Mumbai, India. 


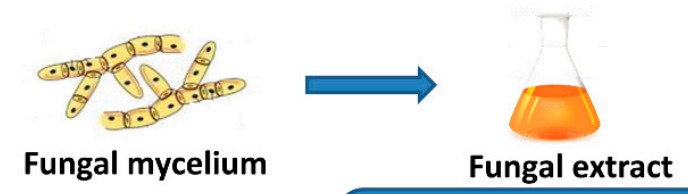

(Polysaccharides, Enzymes

Proteins, Flavonoids, Terpenoids,

Phenolic acid, Organic acids,

Alkaloids, etc.)
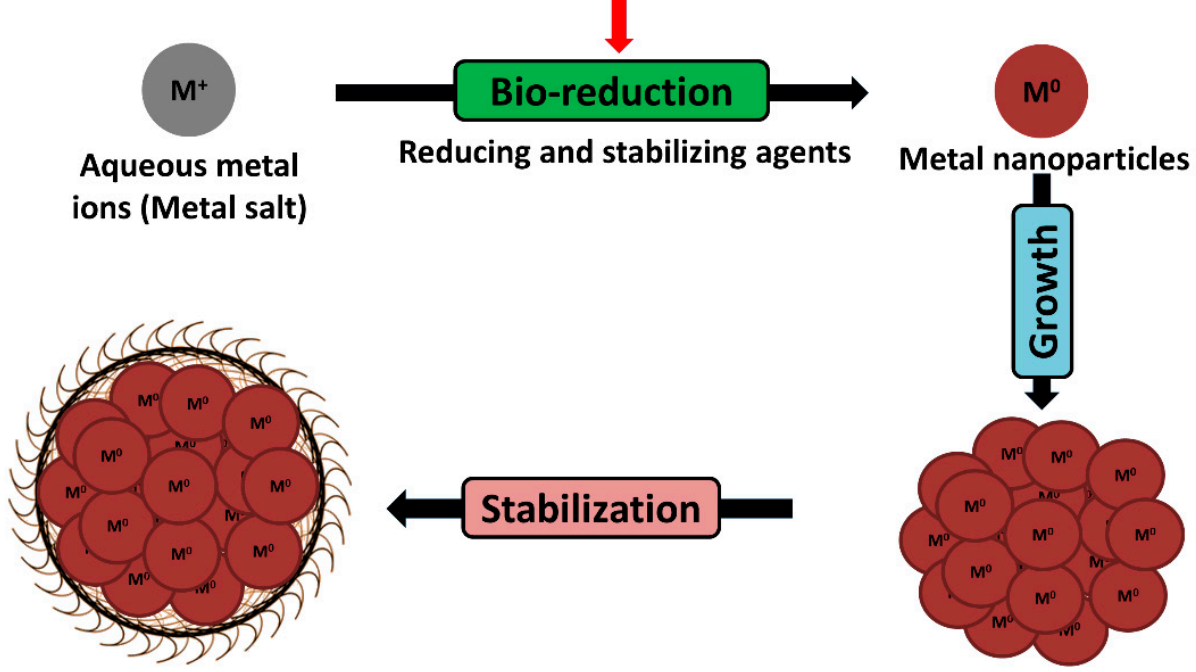

Figure 3. General mechanism involved in the synthesis, growth, and stabilization of metal nanoparticles using fungus.

In addition, Duran et al. [68] and Kumar et al. [69] proposed almost similar mechanisms for the biosynthesis of AgNPs from F. oxysporum. In the former study, the authors reported the role of anthraquinone and the NADPH-nitrate reductase in the biosynthesis of AgNPs, and it was hypothesized that the electron required to fulfill the deficiency of aqueous silver ions $\left(\mathrm{Ag}^{+}\right)$and convert it into $\mathrm{Ag}$ neutral $\left(\mathrm{Ag}^{0}\right.$ i.e., $\left.\mathrm{AgNPs}\right)$ was donated by both quinone and NADPH. However, in the later study, it was demonstrated that the reduction of NADPH to $\mathrm{NADP}^{+}$and the hydroxyquinoline possibly acts as an electron shuttle transferring the electron generated during the reduction of nitrate to $\mathrm{Ag}^{+}$ions, converting them to $\mathrm{Ag}^{0}$ (Figure 4).

There are reports suggesting various hydroquinones to act as electron shuttles reducing the metal ions. F. oxysporum f. sp. cubense JT1 demonstrated to have the capacity to reduce the gold ions to AuNPs [48]. Moreover, as per Ahmad et al. [16], the capacity of reducing metal ions is species-specific. The reductase specific to F. oxysporum and F. moniliforme were not able to synthesize AgNPs intracellularly and extracellularly. In addition to extracellular mechanisms, there are few mechanisms proposed for intracellular mycosynthesis of metal nanoparticles. In the case of Fusarium-mediated intracellular mycosynthesis, metal nanoparticles usually formed below the cell surface and this may be due to the reduction of metal ions by metabolites (i.e., enzyme) present in the cell membrane. Generally, a two-step mechanism has been proposed for intracellular mycosynthesis of nanoparticles. In the first step, aqueous metal ions are attached to the fungal cell surface by the electrostatic interaction between lysine residues and metal ions $\left(\mathrm{M}^{+}\right)$. However, in the second step, the actual mycosynthesis of nanoparticles occurs by the enzymatic reduction of metal ions $\left(\mathrm{M}^{0}\right)$, which leads to the aggregation and formation of nanoparticles [49] (Figure 5). 


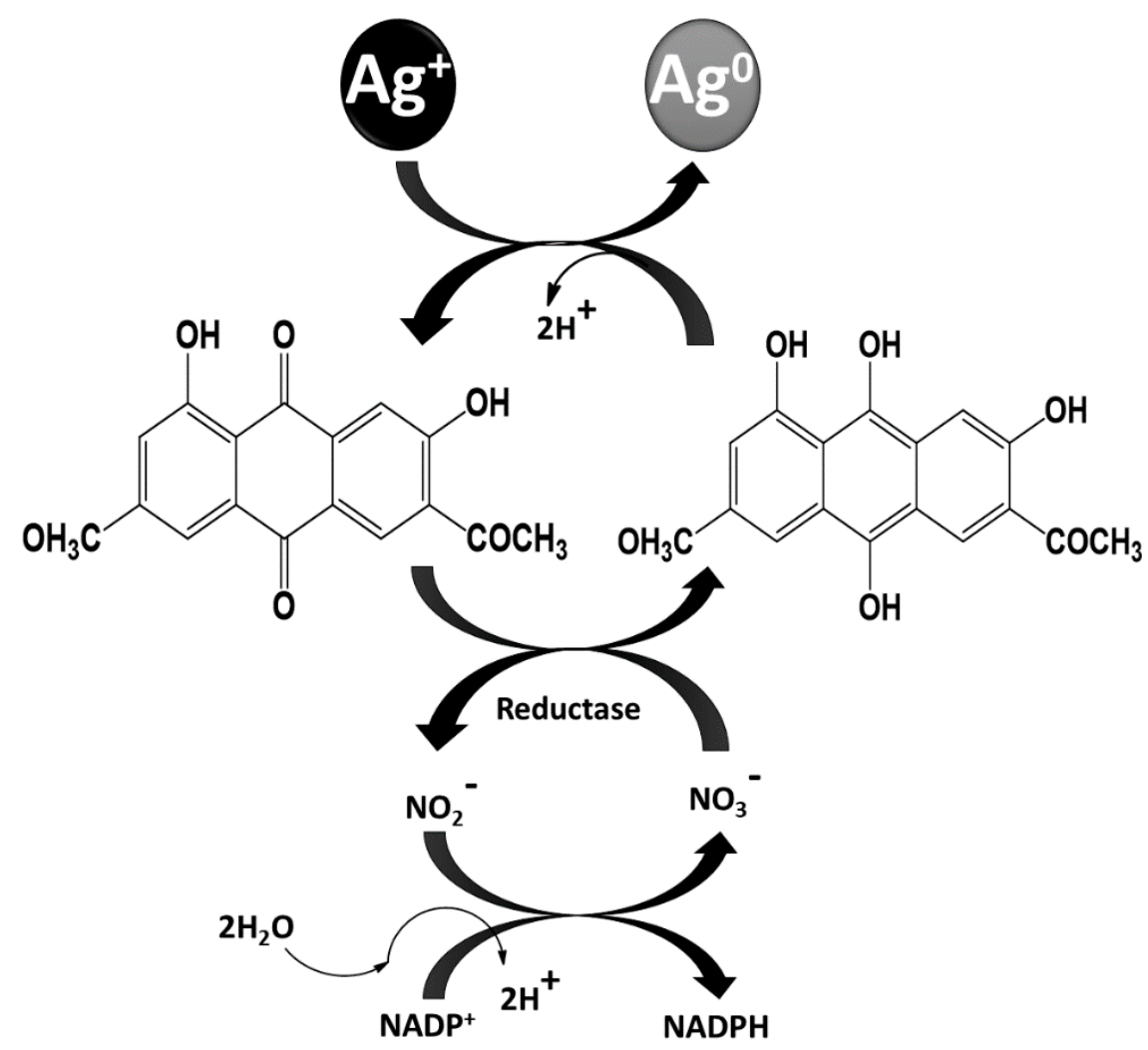

Figure 4. Hypothetical mechanism of AgNPs biosynthesis from F. oxysporum (Adapted from Duran et al. [67], an open-access article).

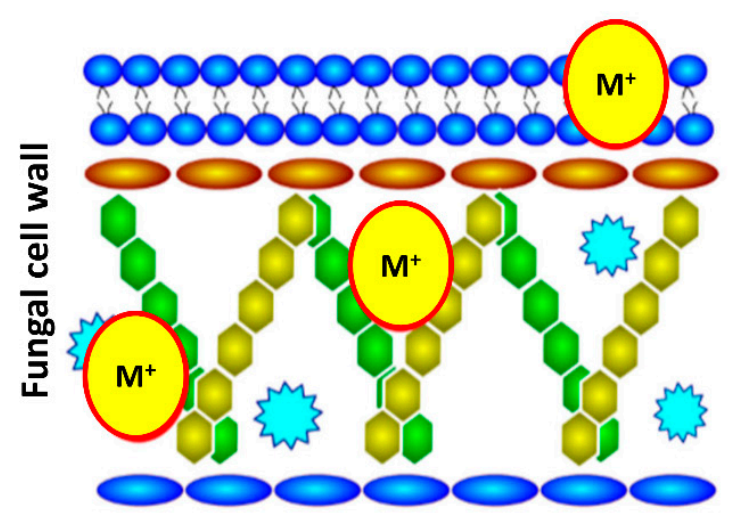

Entrapment of metal ions

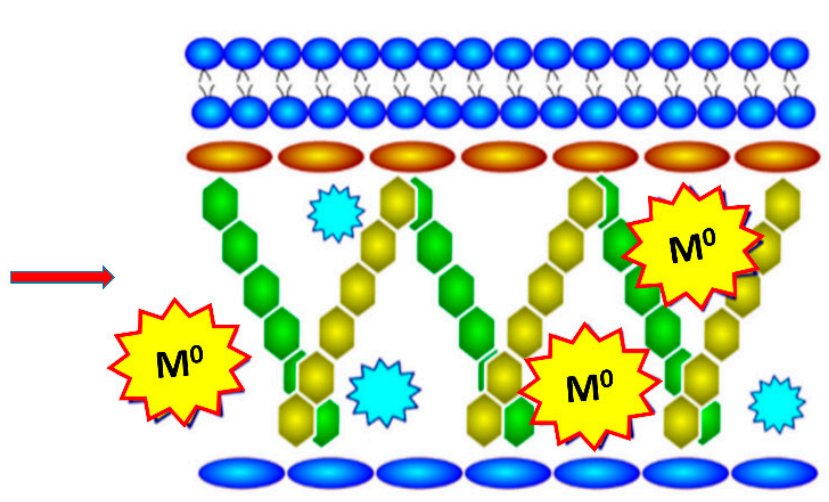

Reduction of metal ions and formation of nanoparticles

Figure 5. Hypothetical intracellular mechanisms for the synthesis of metal nanoparticles from F. oxysporum (Adapted and modified from Yadav et al. [13]; with copyright permission from Springer).

Moreover, various other studies performed on mycosynthesis proposed the role of different other enzymes and proteins. However, among all these mechanisms for extracellular mycosynthesis, the hypothetical mechanism involving the role of NADHdependent nitrate reductase enzyme has been widely accepted.

\subsection{Biomedical Applications of Nanoparticles Synthesized Using Fusarium Spp.}

Biomedical application is an expanding field of research with tremendous prospects for the improvement of the diagnosis and treatment of human diseases [70]. The dispersed 
nanoparticles are usually employed in nanobiomedicine as fluorescent biological labels [71], as well as drug and gene delivery agents [72].

The biologically synthesized AgNPs could have many applications in areas such as non-linear optics, spectrally selective coating for solar energy absorption and intercalation materials for electrical batteries, as optical receptors, catalysis in chemical reactions, bio labelling [73], and as antibacterial agents [74-76]. The biomedical applications of Fusarium-mediated synthesized nanoparticles are shown in Figure 6.

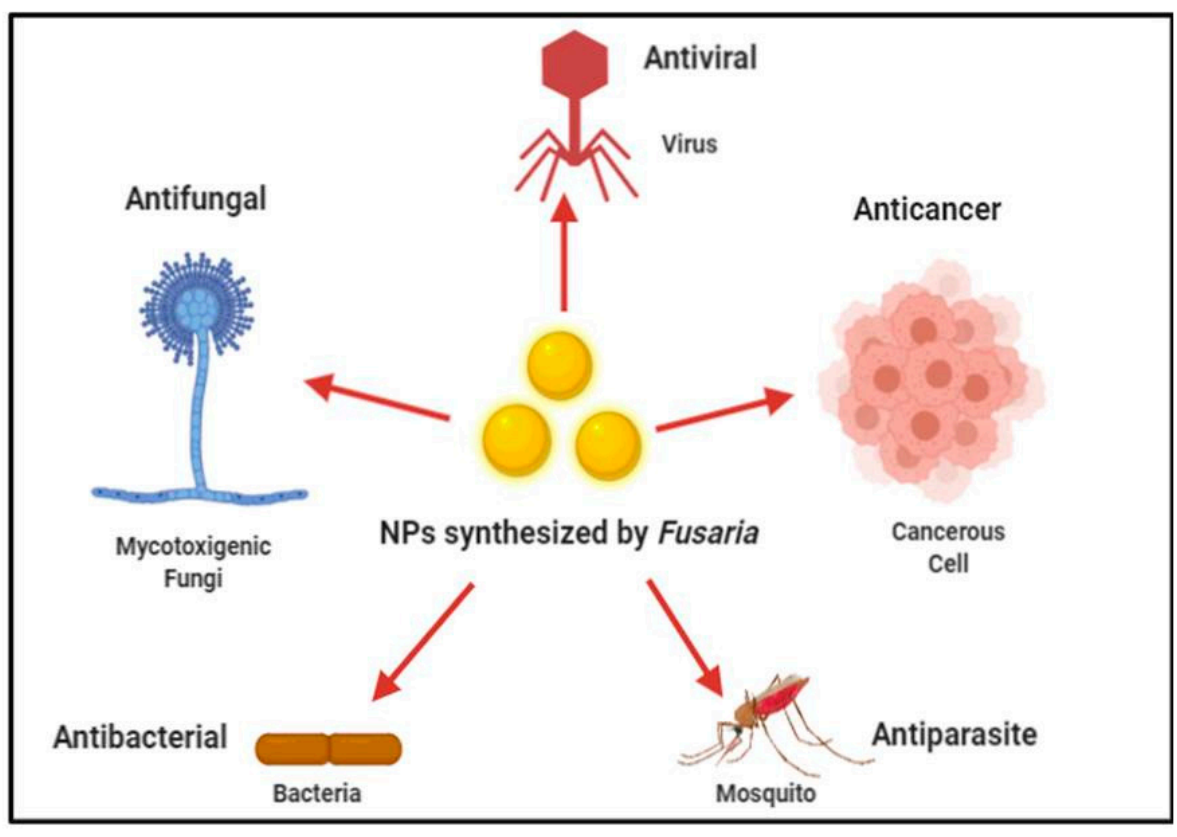

Figure 6. Biomedical applications of biogenic NPs synthesised from different Fusaria.

\subsubsection{Antibacterial Activity of Nanoparticles}

Gupta and Chundawat [41] used Fusarium oxysporum for the production of platinum nanoparticles. The zones of inhibition against microbes were studied by the agar well diffusion and agar dilution methods. It helps to know the minimum inhibitory concentration of platinum NPs. The minimum inhibitory concentration of platinum NPs was found to be $62.5 \mu \mathrm{g} \mathrm{ml}^{-1}$ for $E$. coli, which is relatively better than that of commercially available drug ampicillin. Also, the antioxidant activity was studied by the $\alpha, \alpha$-diphenyl$\beta$-picrylhydrazyl (DPPH) method and platinum nanoparticles showed 79\% scavenging activity. Duran and his co-workers [68] synthesised AgNPs by Fusarium oxysporum and integrated into the textile fabric for the inhibition of bacterial contamination such as Staphylococcus aureus.

The uropathogenic Escherichia coli (UPEC) form biofilms. The prevalence of urinary tract infections (UTIs) is due to the inaccessibility of the antibiotics into the highly complex structure of the biofilm. However, with the appearance of antibiotic multi-resistant UPEC strains, alternatives to the treatment of UTIs are fewer. AgNPs are an effective treatment of UPEC infections due to its physicochemical properties that confer them antibacterial activity against biofilm structured cells [54].

\subsubsection{Antiviral Activity of Nanoparticles}

The interaction between AgNPs and viruses is attracting pronounced interest due to the potential antiviral activity of these particles. Elechiguerra et al. [77] reported that the smaller AgNPs are capable of reducing viral infectivity by inhibiting attachment to the host cells. It has been established that AgNPs undergo a size-dependent interaction with herpes simplex virus types 1 and 2 , and with human parainfluenza virus type 3 . Also, the authors confirmed that smaller nanoparticles were able to decrease the infectivity of the 
viruses [78]. Gaikwad et al. [30] synthesized AgNPs using Fusarium oxysporum and other fungi, which showed potential for reducing the replication of HSV-1, HSV-2, and HPIV-3 in cell cultures. The AgNPs formed by F. oxysporum were the most effective and presented low cytotoxicity [9].

\subsubsection{Anticancer Activity of Nanoparticles}

Husseiny et al. [79] reported the antibacterial and antitumor potential of AgNPs synthesized from Fusarium oxysporum. The nanoparticles were effective to inhibit $E$. coli and S. aureus, and also a tumor cell line. A low IC50 value $\left(121.23 \mu \mathrm{g} \mathrm{cm}^{-3}\right)$ for MCF-7 cells (human breast adenocarcinoma) was gained following exposure of the cells to the nanoparticles, indicating high cytotoxicity and the potential for tumor control. The effect was recognized by the involvement of the AgNPs in the disruption of the mitochondrial respiratory chain, which led to the production of reactive oxygen species and hindered the production of adenosine triphosphate (ATP), consequently damaging the nucleic acids.

Clarance et al. [60] explored the anticancer potential of the AuNPs obtained by the green synthesis method using an endophytic strain Fusarium solani ATLOY-8 isolated from Chonemorpha fragrans. The AuNPs were tested for their cytotoxicity on cervical cancer cells (He La) and human breast cancer cells (MCF-7); the NPs exhibited dose-dependent cytotoxic effects. The results delivered an apparent and versatile biomedical application for a safer chemotherapeutic agent with little systemic toxicity.

\subsubsection{Antifungal Activity of NPs}

Bansod et al. [34] reported bioconjugate-nano-PCR as a rapid and specific method for the identification of Candida species in less time. The DNA sample of Candida albicans was conjugated with AuNPs and AgNPs synthesized from F. oxysporum. The use of this nanoparticle-altered template enhances the sensitivity and specificity of the traditional PCR assay. It is helpful in molecular diagnostics and therapeutics. It is demonstrated as an effective method for the identification of Candida sp. with a low concentration of DNA and less time. In another study, it was demonstrated that AgNPs synthesized by F. oxysporum were inhibitory to pathogenic fungi such as Candida and Cryptococcus [76].

Horky et al. [80] summarized the current findings of mycotoxins and their elimination by nanoparticles. They concluded that nanomaterials have interesting adsorption properties, which make them promising for mycotoxin elimination.

\subsubsection{Antiparasitic Activity Against Vectors}

Some studies showed that AgNPs synthesized from different fungal species can be employed in pest control [81]. In a study, Dhanasekaran and Thangaraj [82] evaluated the larvicidal activity of biogenically synthesized AgNPs against the larvae of Culex mosquito vector, which causes filariasis. The authors reported that $5 \mathrm{mg} / \mathrm{L} \mathrm{AgNPs}$ were responsible for $100 \%$ mortality of the Culex larvae. This research has opened a new area of research that the biogenically synthesized AgNPs can be used for the control of mosquito vectors causing diseases like filaria, malaria. dengue, etc.

\section{Applications in Agriculture}

Agriculture plays a major role in the economy as it is the backbone of most developing countries. The worldwide population is growing day-by-day very rapidly and it is predicted that it will reach about eight billion by 2025 and 9.6 billion by 2050. It is widely recognized that global agricultural productivity must increase to feed a rapidly growing world population [83-85]. For the improvement in crop productivity, nanotechnology provides new agrochemical agents and new delivery mechanisms, and it promises to reduce pesticide use as NPs could be used in the variable applications concerned with agriculture. The applications of nanotechnology (as shown in Figure 7) can boost agricultural production, which includes the nano-formulations of agrochemicals to use as pesticides and fertilizers for crop improvement, nano-biosensors in crop protection for the 
identification of diseases and residues of agrochemicals, and nano-devices for the genetic manipulation of plants, etc. In agriculture, nanobiotechnology is used to improve the food production, with corresponding or even higher values of nutrition, quality and safety. Efficient application of pesticides, fertilizers, herbicides and plant growth regulators is the very critical way to get better crop production [86,87]. Nanocarriers could be used to achieve the controlled release of herbicides, pesticides, and other plant growth regulators. For example, poly (epsilon-caprolactone) nanocapsules have been recently developed as a herbicide carrier for atrazine [88]. The mustard plants (Brassica juncea) when treated with atrazine-loaded poly (epsilon-caprolactone) nanocapsules more significantly boosted the herbicidal activity than that of commercial atrazine, demonstrating a drastic decline in net photosynthetic rates. Moreover, the stomatal conductance and oxidative stress increased considerably, which ultimately reduced the weight and growth of the plants [88]. Likewise, other nanocarriers such as silica nanoparticles [89] as well as polymeric nanoparticles [43] have also been developed for delivering the pesticides in a prescribed manner. Nanocarriers could be employed to perfectly achieve the delivery as well as the slow release of these species, which is known as "precision farming". This helps to improve the crop yield without damaging the soil and water [90].

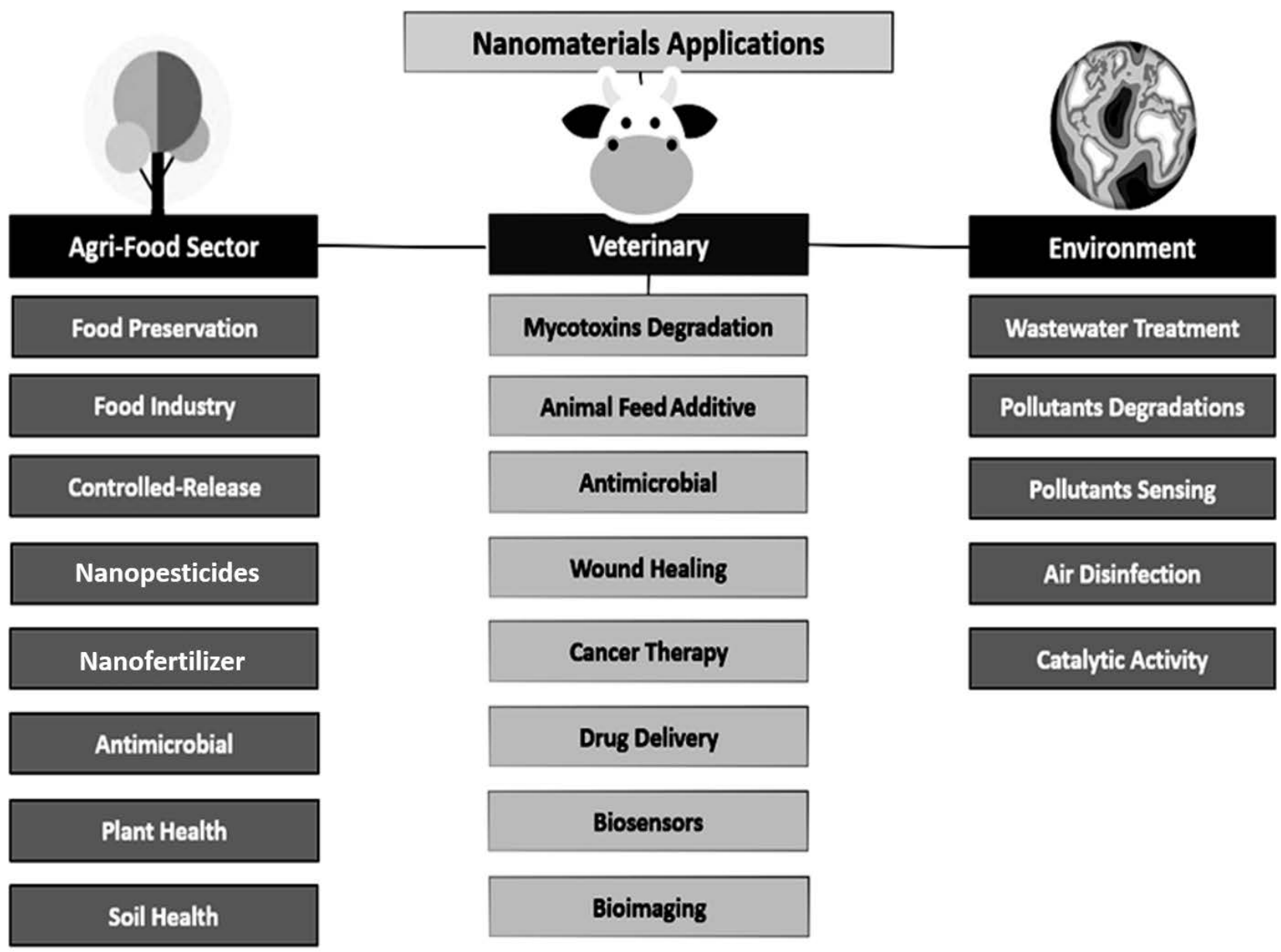

Figure 7. Applications of Nanotechnology in agri-food, veterinary medicine, and environment.

Most significantly, the application of nanoencapsulation could lower down the herbicide dosage leading to a safer environment. In addition to nanocarriers, NP-mediated gene transfer in plants was employed for the development of insect-resistant crop varieties. The detailed account for the gene or DNA transfer could be established in earlier available reviews [91,92]. Al-Askar et al. [75] demonstrated that AgNPs biosynthesized 
by F. solani isolated from wheat were shown to be effective for the treatment of wheat, barley, and maize seeds contaminated by different species of phytopathogenic fungi. Moreover, metal oxide nanomaterials such as $\mathrm{CuO}, \mathrm{TiO}_{2}$, and $\mathrm{ZnO}$ are extensively studied for plant protection from pathogen infections because of their intrinsic toxicity. For example, ZnONPs efficiently inhibited fungal growth such as F. graminearum [93], Aspergillus flavus, Aspergillus fumigatus, Aspergillus niger, F. culmorum and F. oxysporum [94]. The use of CuNPs as an antimicrobial agent against plant pathogens has been reported in several publications $[95,96]$. Mineral fertilizers used conventionally undergo substantially high losses besides lower uptake efficiencies of the nutrients. Those economic losses will be overcome by the development of nanofertilizers, which could be the novel solution. Nanofertilizers can reduce the nutrient loss as well as increasing nutrient adaptation by soil microbes and crops [97]. Nanofertilizers are mainly the micro-nutrients at nanoscale for $\mathrm{Mn}, \mathrm{Cu}, \mathrm{Fe}, \mathrm{Zn}$, $\mathrm{Mo}, \mathrm{N}$, and $\mathrm{B}$, and are commercialized and available under different brand names in the market such as Nano-Ag Answer ${ }^{\circledR}$, NanoPro ${ }^{\mathrm{TM}}$, NanoRise ${ }^{\mathrm{TM}}, \mathrm{NanoGro}^{\mathrm{TM}}, \mathrm{NanoPhos}^{\mathrm{TM}}$, NanoK $^{\mathrm{TM}}$, NanoPack ${ }^{\mathrm{TM}}$, NanoStress ${ }^{\mathrm{TM}}$, NanoZn ${ }^{\mathrm{TM}}$, $\mathrm{pH}^{\circledR}{ }^{\circledR}$, etc. [87]. The use of other nanomaterials as an alternative for the typical conventional crop fertilizers, such as carbon nano-onions [98] and chitosan nanoparticles [99], was noted to boost the crop growth and quality. Shende et al. [100] reported the plant growth-promoting activity of biogenic CuNPs on pigeon pea (Cajanus cajan L.) crops that suggested the use of these nanoparticles as a nanofertilizer for the development of sustainable agriculture. It is estimated that the novel nanofertilizers will encourage and makeover current fertilizer production industries in the next decade [87].

Because of several advantageous characteristics of nanomaterials, nanosensors, particularly wireless nanosensors, have also been developed to monitor nutrient efficiency in crop plants, crop diseases, and growth, along with the environmental conditions in the field. Particularly, engineered nanosensors are capable of detecting chemicals like pesticides, herbicides, and pathogens at trace amounts in food and agricultural systems. Such an in situ and real-time monitoring system facilitates the remediation of probable crop losses as well as perking up the crop production, accompanied by the suitable application of nanopesticides, nanoherbicides, and nanofertilizers. Abbacia et al. [101] reported that the copper-doped montmorillonite will possibly be used for on-line monitoring of propineb fungicide in an aquatic environment i.e., in both fresh and salty water, with a low detection limit of about $1 \mathrm{mM}$ [101]. In another study, it was demonstrated that the nanomaterials such as graphene could be developed for the detection of the pathogen in wastewater [102] and purification of drinking water can be carried out [103], signifying its potential application in aquaculture. Moreover, various other nanomaterials like carbon nanotube [104], CuNPs [105], AgNPs [106], and AuNPs [107] can be used as nanosensors designed for the real-time monitoring of crop health and growth along with the environmental conditions in the field. Table 2 showed different Fusarium isolates used in the green synthesis of nanoparticles.

Table 2. Fusarium isolates used in the green synthesis of different NPs.

\begin{tabular}{|c|c|c|c|c|}
\hline Name of Fungi & Synthesised NPs & Localization & Size (in $\mathrm{nm}$ ) and Shape & References \\
\hline Fusarium oxysporum & $\mathrm{Ag}$ & Extracellular & $\begin{array}{c}10-20 \text { and Spherical } \\
25-50 \text { and almost spherical } \\
- \\
5-13 \text { and Spherical } \\
23 \text { and Spherical }\end{array}$ & $\begin{array}{c}\text { Birla et al. [33] } \\
\text { Korbekandi et al. [108] } \\
\text { Ishida et al. [76] } \\
\text { Husseiny et al. [79] } \\
\text { Hamedi et al. [109] }\end{array}$ \\
\hline Fusarium verticillioides & $\mathrm{Ag}$ & Extracellular & - & Mekkawy et al. [61] \\
\hline Fusarium semitectum & $\mathrm{Au}$ & - & 25 and Spherical & Sawle et al. [54] \\
\hline Fusarium oxysporum & $\mathrm{Au}$ & - & 2-50 and Spherical, monodispered & Zhang et al. [110] \\
\hline Fusarium oxysporum & $\mathrm{Au}-\mathrm{Ag}$ bimetallic & Extracellular & 8-14 and Quasi-spherical & Senapati et al. [111] \\
\hline Fusarium semitectum & Au-Ag alloy & - & 25 and Spherical & Sawle et al. [55] \\
\hline Fusarium oxysporum & $\mathrm{Fe}_{3} \mathrm{O}_{4}$ & Extracellular & 20-50 and Irregular, quasi-spherical & Bharde et al. [42] \\
\hline
\end{tabular}


Table 2. Cont

\begin{tabular}{|c|c|c|c|c|}
\hline Name of Fungi & Synthesised NPs & Localization & Size (in $\mathrm{nm}$ ) and Shape & References \\
\hline Fusarium oxysporum & $\mathrm{Pt}$ & - & $\begin{array}{l}\text { 70-180 and Rectangular, triangular, } \\
\text { spherical and aggregates }\end{array}$ & Govender et al. [112] \\
\hline $\begin{array}{l}\text { Fusarium oxysporum } \mathrm{f} . \\
\text { sp. lycopersici }\end{array}$ & $\mathrm{Pt}$ & Extra-and intracellular & $\begin{array}{l}10-100 \text { and Hexagonal, pentagonal, } \\
\text { circular, squares, rectangles }\end{array}$ & Riddin et al. [50] \\
\hline Fusarium spp. & $\mathrm{Zn}$ & Intracellular & $\begin{array}{c}\text { 100-200 and Irregular, some } \\
\text { spherical }\end{array}$ & Velmurugan et al. [113] \\
\hline
\end{tabular}

\section{Toxicity of Fusarium Nanoparticles}

Nanoparticles are unique materials as they have property combinations compared with conventional materials [114]. There is a wide range of applications of NPs such as in human health appliances, industrial, medical and biomedical fields, engineering, electronics, and environmental applications [115]. Among all nanomaterials, AgNPs are the most widely used in medicine, medicinal devices, pharmacology, biotechnology, electronics, engineering, energy, magnetic fields, and also in environmental remediation [116]. Their highly effective antibacterial activity has found applications in industrial sectors including textiles, food, consumer products, medicine, etc. [117].

The unique physical, chemical and biological (e.g., antimicrobial, anticancer, antiparasitic) properties of nanoparticles differ largely from corresponding bulk materials and make them a high-demand material in different sectors. However, the widespread and increased use of nanoparticles may pose a risk to both the environment and living organisms by increasing the level of toxicity [118]. To date, several studies have used different model cell lines to exhibit the cytotoxicity of nanoparticles from Fusarium species, mainly AgNPs, and their underlying molecular mechanisms $[31,60,65,119]$. Biogenic nanoparticles are capped with natural molecules like proteins [120-122]. This capping is defined as corona. This nanoparticle corona significantly affects the biological response [123]. Based on the surface affinity and exchange rate, the corona can be divided into two forms: hard corona and soft corona. The soft corona proteins are 'vehicles' for the silver ions, whereas the hard coronas are rigid for the trespass into the cellular system [124]. The functional groups of the corona play a key role in the formation of the nanoparticle-protein corona [125]. These functional groups along with the protein charges also regulate the cytotoxic properties of the nanoparticle corona $[123,125]$. The surface charge of nanoparticles plays an important role in their bactericidal activity against both Gram-positive and Gram-negative bacteria, as exemplified by AgNPs [126]. It was confirmed using transmission electron microscopy (TEM) that AgNPs can penetrate cellular compartments such as endosomes, lysosomes, and mitochondria [127]. Several reports indicate that the proteins contained in the nanoparticle corona interact with the cells and not the nanoparticles themselves [128,129]. Thus, the corona formation and composition have important implications for both toxicity [130] and internalization [131].

To sum up, particle size [132], particle shape [133], particle surface properties [134], biological fluid properties, and composition affect the corona structure and thus the adverse effects on human health and the environment [131,135].

\subsection{Effect of Size and Shape of Nanoparticles on Cytotoxicity}

It is claimed that apart from the size, the shape of nanoparticles affects their toxicity to cells. Mohamed et al. [31] investigated the cytotoxicity of the two different shapes of zinc oxide nanoparticles (ZnONPs) biosynthesized from Fusarium keratoplasticum (A1-3) and Aspergillus niger (G3-1). These nanoparticles displayed a similar size (10-42 and 8-38 nm) but different shapes, namely hexagonal and nanorods, respectively. It was reported that a safe dose of these nanoparticles for applications in animal cells should be lower than 20.1 and $57.6 \mathrm{ppm}$, respectively. Therefore, the rod ZnONPs were more applicable to safety at high concentrations in contrast to hexagonal ZnONPs [31]. Soleimani and co-authors [136] studied biological activity of different shapes (cube, sphere, rice and rod) of AgNPs synthe- 
sized using chitosan in acetic acid solution and $0.2 \mathrm{M}$ of $\mathrm{AgNO}_{3}$ (cubes) and F. oxysporum, starch and $0.08 \mathrm{M}$ of $\mathrm{AgNO}_{3}$ at $\mathrm{pH} 6.8$ (spheric) or $1.0 \mathrm{M}^{\circ} \mathrm{AgNO}_{3}$ at $\mathrm{pH} 3.0$ (nanorice), and finally, F. oxysporum, starch and $1.2 \mathrm{M} \mathrm{AgNO}_{3}$ at $\mathrm{pH} 3.0$ and $30^{\circ} \mathrm{C}$ for 3 days (blunt ends rods) or with 10-days incubation (sharp-ends rods). They found that silver nanostructures with different shapes are not inherently toxic to human cells at concentrations lower than $10 \mu \mathrm{g} \mathrm{ml}^{-1}$, whereas for higher concentrations cell viability decreased in a shape and dose-dependent manner. Nanocubes, nanorice and sharp-nanorods were found to be more toxic than spheres and blunt-nanorods. The former significantly decreased cell viability at concentrations $25 \mu \mathrm{g} \mathrm{mL}^{-1}$ or higher, and the latter at concentrations of 50 and $75 \mu \mathrm{g} \mathrm{mL}{ }^{-1}$. Moreover, they showed that cubic nanoparticles inhibited the growth of all tested bacteria (Bacillus subtilis, Staphylococcus aureus, Escherichia coli, and Pseudomonas aeruginosa) at the lowest-used concentrations (10 ppm). The toxic effect of nanostructures against bacterial cells increased in order spheres, blunt-rods, nanorice, sharp-rods, and nanocubes [136]. It was concluded that due to stronger vertex in sharp ends of silver nanostructures, some geometries of AgNPs, especially cubic structures, have more interaction with the bacterial cell membrane, resulting in stronger biological activity [136]

\subsection{Mechanisms of Nanoparticle Cytotoxicity}

The increased use of AgNPs also increases the concentration of silver ions in soil and water that can adversely affect human and animal health or the environment $[137,138]$.

Little is known about the diversified mechanisms of the action of nanoparticle cytotoxicity, as well as their short- or long-term exposure outcomes on human physiology [139,140]. Many authors claim that the silver ions released from AgNPs through the surface oxidation are the main mechanism that induces cytotoxicity, genotoxicity, immunological responses in biological systems and even cell death [141-145].

Several recent studies revealed that cytotoxicity of AgNPs occur due to the minimum release of silver ions [146-148]. Sambale et al. [149] showed that the mechanism of cell death is different when cells are cultivated with silver particles or ions. Cells treated with particles suffered apoptosis while those cultivated with ions die due to necrosis. They also reported that AgNPs that translocate into cytoplasm through diffusion or channel proteins are oxidized by cytoplasmic enzymes, thereby releasing silver ions. These ions may interact with thiol groups of mitochondrial membrane proteins, causing mitochondrial dysfunction and generating reactive oxygen species (ROS) production [149].

\subsection{Effect of Nanoparticles on Cell Membranes}

Nanosilver can interact with cellular membranes and cause toxicity. In particular, nanosilver can interact with the bacterial membrane and this is considered the main mechanism for the antimicrobial toxicity of nanosilver. The AgNPs damaged and destroyed bacterial cells by penetrating and accumulating in the bacterial membrane [150-152]. Khan et al. [153] studied the interaction of nanosilver with five types of bacteria. They found that the adsorption of nanosilver on the bacterial surface or interaction with extracellular proteins is dependent on $\mathrm{pH}$, zeta potential, and $\mathrm{NaCl}$ concentration. Baruwati et al. [154] studied "green" synthesized nanosilver from Chinese green tea (Camellia sinensis) and found that exposure to these particles alters the membrane permeability of barrier cells (intestinal, brain endothelial) and stimulates oxidative stress pathways in neurons [154].

Metal nanoparticles (copper, silver and zinc oxide) from Fusarium solani KJ 623702 were tested against multidrug-resistant bacteria (P. aeruginosa and S. aureus), E. coli, Klebsiella pneumoniae and Entreococcus sp. and mycotoxigenic Aspergillus awamori, A. fumigatus and F. oxysporum. The antimicrobial activity of metal nanoparticles increased as follows: CuNPs, ZnONPs, and AgNPs. Besides the internalization of AgNPs with the cell wall resulting in the presence of pits, the fragmentation, complete disappearance of cellular contents, disorganization and leakage of internal components were observed after treatment of microorganisms with mycogenic AgNPs. Authors claimed that AgNPs attach to the microbial cell membrane and alter its structure, transport activity, penetrability, prompt 
neutralization of the surface electric charge and produce cracks and pits through which internal cell contents are effluxed [44].

Moreover, AgNPs synthesized using F. oxysporum filtrate containing reductase enzymes and quinones showed a toxic effect on the human liver cell line (Huh-7). The $\mathrm{IC}_{50}$ values were found to be $11.12 \mu \mathrm{M}$ for propidium iodide assay which is an intercalating fluorescent dye and does not permeant to live cells [155]. Similarly, cell viability (hamster lung fibroblasts, V79) after the treatment with AgNPs synthesized from F. oxysporum was studied using neutral red uptake (NRU) assay [156]. These small (around $8 \mathrm{~nm}$ ) nanoparticles showed a non-cytotoxic effect on fibroblasts at concentrations until $16 \mu \mathrm{M}$. The $\mathrm{IC}_{50}$ of mycogenic AgNPs was recorded at a concentration of $22 \mu \mathrm{M}$ [156].

Vijayan et al. [157] estimated the release of haemoglobin from red blood cells due to the disruption of the cell membrane by the AgNPs from F. oxysporum. The percentage of haemolysis increased from 3.8 to 32.0 with an increase in AgNPs concentration from 25 to $150 \mu \mathrm{g} \mathrm{ml}^{-1}$ (at $25 \mu \mathrm{g} \mathrm{ml}^{-1}$ interval unit). The authors concluded that these biogenic AgNPs are safe to use as a drug because at safe concentrations they showed antibacterial effect against Escherichia coli, Klebsiella pneumoniae, Pseudomonas aeruginosa and Salmonella typhi [157].

\subsection{Effect of Nanoparticles on Mitochondria and/or Metabolic Activity}

Nanoparticles by mitochondrial membrane damage disturb respiratory chain activity and ATP synthesis may generate ROS production, leading to oxidative stress and eventually apoptosis $[158,159]$. Many authors reported the effect of metal (Ag and Au) and non-metal (selenium) nanoparticles from Fusarium species on the viability of human or animal cells on the basement of activity of cell/mitochondrial enzymes using mainly spectrophotometrical MTT (3-(4,5-dimethylthiazol-2-yl)-2,5-diphenyltetrazolium bromide) assay $[155,156,160,161]$.

The toxicity of AuNPs produced by F. oxysporum with sizes of around 20 to $50 \mathrm{~nm}$ was measured by MTT assay [161]. The biologically produced AuNPs had a dose-dependent toxic effect on the human fibroblast cell line (CIRC-HLF). The $\mathrm{IC}_{50}$ value of the NPs was determined as $2.5 \mathrm{mg} \mathrm{mL}^{-1}$ [161]. The AuNPs from Fusarium solani ATLOY-8 strain were studied against cancer cell lines, namely HeLa na MCF-7 (breast cancer cells) and the human embryonic kidney (HEK) cell line using MTT assay. The anticancer potential of NPs against both cancer cell lines $\left(\mathrm{IC}_{50}\right.$ values of 1.3 and $0.8 \mathrm{mg} \mathrm{mL}^{-1}$, respectively) and their insignificant activity on the HEK cell line was reported [60].

AgNPs from Fusarium oxysporum were studied on mouse fibroblasts (3T3), hamster lung fibroblasts (V79 line), and human liver (Huh-7) cells using MTT and calcein assays [155,156,161]. AgNPs showed dose-dependent toxic effects on the mouse fibroblast. $\mathrm{IC}_{50}$ of mycogenic nanoparticles using MTT assay were found to be $0.312 \mathrm{mg} \mathrm{mL}^{-1}\left(=1.187 \mathrm{ppm} \mathrm{mL}^{1}\right)$. The applied concentrations of the silver NPs equal to $0.625 \mathrm{mg} \mathrm{mL}^{-1}\left(2.375 \mathrm{ppm} \mathrm{mL}^{-1}\right.$ ) was determined as the toxic dose [60]. Marcato and coauthors [156] reported that AgNPs synthesized using Fusarium oxysporum showed a non-cytotoxic effect toward the V79 fibroblast cell line until $16 \mu \mathrm{M}$, evaluated by MTT assays with an $\mathrm{IC}_{50}$ of $22 \mu \mathrm{M}$; this was similar in NRU assay. AgNPs synthesized using F. oxysporum filtrate demonstrated a comparable dose-response relationship and similar $\mathrm{IC}_{50}$ values of $10.61 \mu \mathrm{M}$ for MTT and $9.10 \mu \mathrm{M}$ for calcein assay [155]. Small AgNPs (5-13 nm) produced by F. oxysporum were also found to be toxic to the human breast carcinoma cell line (MCF-7). The $\mathrm{IC}_{50}$ value of these NPs was found to be $121.23 \mu \mathrm{g} \mathrm{mL}^{-1}$ [78].

Another species of the genus Fusarium, namely F. semitectum, was used for the synthesis of selenium nanoparticles (SeNPs) which were tested for their anticancer potential on Caco2 human colon cancer, A431 skin cancer, and SNU16 stomach gastric cancer cell lines, as well as toward THLE2 normal liver and Vero normal kidney cell lines [57]. These biogenic SeNPs showed anticancer potential toward colon, skin, and stomach gastric cancer cells (IC 50 of $10.24,13.27$ and $20.44 \mu \mathrm{g} \mathrm{mL}^{-1}$, respectively), no cytotoxic effects on normal liver cells, and weak toxicity on normal kidney cells [57]. 


\subsection{Effect of Nanoparticles on Cell Proteins}

Many authors have reported that silver ions and AgNPs can interact with various chemical groups, including sulfide and chloride [162,163]. Thiol molecules are found to be conjugated to several membrane proteins in the cell membrane, cytoplasm and mitochondria, which may serve as targets for AgNPs or $\mathrm{Ag}^{+}$ions [164]. AgNPs also bind to thiol groups in enzymes, such as NADH dehydrogenase, and disrupt the respiratory chain, finally generating ROS. As shown in studies by Soleimani et al. [136] the cubic AgNPs from F. oxysporum at a concentration of $30 \mathrm{ppm}$ not only caused a toxic effect in MCF-7 cells and inhibited growth of the Gram-positive and Gram-negative bacteria, but also completely degraded proteins (albumin), whereas other shaped nanoparticles (rods, rice and spheres) had no denaturing effect on protein structure. They concluded that cubic nanosilver displays stronger biological activity when compared to rod and spherical AgNPs [136].

\subsection{Effect of Nanoparticles on Cell Nucleic Acids}

AgNPs, especially those smaller than $10 \mathrm{~nm}$, have been shown to diffuse through the nuclear pores into the nucleus, causing DNA damage, chromosomal aberrations, and cell cycle arrest, resulting in genotoxicity in human cell lines (e.g., fibroblasts and glioblastoma cells) $[162,163]$.

Clarance et al. [60] studied the effect of mycogenic AuNPs on cancer cells using dual $\mathrm{AO} / \mathrm{EtBr}$ (acridin orange/ethidium bromide) staining. The cell line appeared as a dense red colour after treatment with nanogold, which was mainly due to apoptotic cell death. The DAPI staining revealed nuclear fragmentation and condensation in MCF-7 cells treated with AuNPs. It is well-proven that when cells undergo an apoptotic death, their DNA becomes dense, fragmented and with condensed chromatin [165,166].

It was also reported that the interaction of AgNPs synthesized from Fusarium mangiferae with DNA in Staphylococcus aureus cells resulted in an enormous reduction or degradation of both chromosomal and plasmid DNA in bacterial cells when compared with untreated cells. This gel electrophoresis study of AgNPs-treated nucleic acids also revealed that the RNA smearing was immensely decreased. These results suggest that AgNPs may prevent DNA replication via binding, and lead to cell death [167].

Spherical AgNPs synthesized by using aqueous extracts of green Calligonum comosum stem and Fusarium sp. (mean size of 105.8 and $228.4 \mathrm{~nm}$, respectively) were tested for genotoxicity in bacterial cells (S. aureus). The agarose gel electrophoresis and (UV)-Vis spectrophotometer were used to evaluate the antimicrobial activity of AgNPs by their influence on DNA. A low concentration of DNA was observed in bacterial cells treated with plant-synthesized and mycosynthesized AgNPs when compared to untreated cells. Based on the obtained results, it was concluded that the smaller-sized nanoparticles diffuse more easily than the larger ones, which partially explained the higher toxicity of plantsynthesized than myco-synthesized nanoparticles on S. aureus cells. The destruction of the membrane integrity or inhibition of DNA replication were proposed by authors as AgNPs mechanisms of antibacterial action [58].

\subsection{Other Nanoparticle Activity}

Salaheldin et al. [119] reported that AgNPs synthesized by F. oxysporum caused remarkable vacuolation in the human breast carcinoma cell line (MCF-7), thus indicating potent cytotoxic activity. Al-Sharqi [168] tested these mycogenic AgNPs on mice for 21 days and showed dilation in the collecting tubule and dilation in the renal corpuscle with haemorrhage in the interstitial space between the tubules. Based on performed studies, the authors conclude that AgNPs can enter and translocate within the cell, and that the size of the AgNPs varies with its toxic effects on the cell and the cell organelles. Therefore, it was assumed that all nanoparticles are toxic and most likely only free nanoparticles that can penetrate small organelles such as mitochondria may trigger adverse health effects [168]. 


\section{Conclusions}

The potential of applications of nanotechnology particularly as nanomedicine and in agriculture has generated revolution. The bioinspired synthesis of nanoparticles using fungi is a novel and emerging field of green and sustainable nanotechnology. Among these, Fusarium spp. are the most studied fungi for the biosynthesis of nanoparticles. The process is green, eco-friendly, and economically viable. The applications of different nanoparticles as antimicrobials, and antiparasitic and anticancer agents have attracted the interest of the researchers globally. Moreover, these biogenic nanoparticles, synthesized by Fusaria, have huge potential in agriculture for plant growth promotion, as nanofertilisers and as fungicidal agents of the new generation. However, the mechanism of the synthesis of nanoparticles remains unclear and warrants further studies to unravel the mechanism. Looking at the potential applications of Fusarium-mediated nanoparticles, the toxicity is a major issue that depends upon shape, size, surface charge, and the dose of nanoparticles used. Thus, it can be recommended that Fusarium is a promising and novel fungus for the biosynthesis of nanoparticles and its potential biomedical and agricultural applications.

Author Contributions: The idea was conceived and designed by M.R. and J.T.-W. The review was written by S.B., P.G., A.G., K.A.A.-E., S.S., S.G. and A.P.I. Furthermore, M.R. supervised and edited the manuscript.

Funding: This work was supported additionally through grants from NAWA Programme, Polan.

Institutional Review Board Statement: Not applicable.

Informed Consent Statement: Not applicable.

Data Availability Statement: Not applicable.

Acknowledgments: M.R. and P.G. would like to thank NAWA Programme, Poland for financial support under the grant PPN/ULM/2019/1/00117/DEC/1 2019-10-02.

Conflicts of Interest: The authors have no relevant affiliations or financial involvement with any organization or entity with a financial interest in or financial conflict with the subject matter or materials discussed in the manuscript. This includes employment, consultancies, honoraria, stock ownership or options, expert testimony, grants or patents received or pending, or royalties.

\section{References}

1. Ranjani, S.; Shariq, A.M.; Adnan, M.; Senthil-Kumar, N.; Ruckmani, K.; Hemalatha, S. Synthesis, characterization and applications of endophytic fungal nanoparticles. Inorg. Nano Metal Chem. 2020, 51, 280-287. [CrossRef]

2. Upadhyay, P.K.; Jain, V.K.; Sharma, K.; Sharma, R. Synthesis and applications of ZnO nanoparticles in biomedicine. Res. J. Pharm. Technol. 2020, 13, 1636. [CrossRef]

3. Usman, M.; Farooq, M.; Wakeel, A.; Nawaz, A.; Cheema, S.A.; Rehman, H.U.; Ashraf, I.; Sanaullah, M. Nanotechnology in agriculture: Current status, challenges and future opportunities. Sci. Total. Environ. 2020, 721, 137778. [CrossRef] [PubMed]

4. Yaqoob, A.A.; Ahmad, H.; Parveen, T.; Ahmad, A.; Oves, M.; Ismail, I.M.I.; Qari, H.A.; Umar, K.; Ibrahim, M.N.M. Recent advances in metal decorated nanomaterials and their various biological applications: A Review. Front. Chem. 2020, 8, 341. [CrossRef]

5. Bououdina, M.; Rashdan, S.; Bobet, J.L.; Ichiyanagi, Y. Nanomaterials for biomedical applications: Synthesis, Characterization, and applications. J. Nanomater. 2013, 2013, 1-4. [CrossRef]

6. Paramo, L.A.; Feregrino-Pérez, A.A.; Guevara, R.; Mendoza, S.; Esquivel, K. Nanoparticles in agroindustry: Applications, toxicity, challenges, and trends. Nanomaterials 2020, 10, 1654. [CrossRef]

7. Ramos, M.M.; Morais, E.D.S.; Sena, I.D.S.; Lima, A.L.; De Oliveira, F.R.; De Freitas, C.M.; Fernandes, C.P.; De Carvalho, J.C.T.; Ferreira, I.M. Silver nanoparticle from whole cells of the fungi Trichoderma spp. isolated from Brazilian Amazon. Biotechnol. Lett. 2020, 42, 833-843. [CrossRef]

8. Ahmed, S.; Ahmad, M.; Swami, B.L.; Ikram, S. A review on plants extract mediated synthesis of silver nanoparticles for antimicrobial applications: A green expertise. J. Adv. Res. 2016, 7, 17-28. [CrossRef] [PubMed]

9. Guilger-Casagrande, M.; De Lima, R. Synthesis of silver nanoparticles mediated by fungi: A Review. Front. Bioeng. Biotechnol. 2019, 7, 287. [CrossRef]

10. Ingle, A.; Gade, A.; Pierrat, S.; Sonnichsen, C.; Rai, M. Mycosynthesis of silver nanoparticles using the fungus Fusarium acuminatum and its activity against some human pathogenic bacteria. Curr. Nanosci. 2008, 4, 141-144. [CrossRef] 
11. Ingle, A.; Rai, M.; Gade, A.; Bawaskar, M. Fusarium solani: A novel biological agent for the extracellular synthesis of silver nanoparticles. J. Nanopart. Res. 2009, 11, 2079-2085. [CrossRef]

12. Rai, M.; Yadav, A.; Gade, A. Silver nanoparticles as a new generation of antimicrobials. Biotechnol. Adv. 2009, 27, 76-83. [CrossRef]

13. Yadav, A.; Kon, K.; Kratosova, G.; Duran, N.; Ingle, A.P.; Rai, M. Fungi as an efficient mycosystem for the synthesis of metal nanoparticles: Progress and key aspects of research. Biotechnol. Lett. 2015, 37, 2099-2120. [CrossRef]

14. Rai, M.; Yadav, A.; Bridge, P.; Gade, A. Myconanotechnology: A new and emerging science. In Applied Mycology; Rai, M.K., Bridge, P.D., Eds.; CABI: Wallingford, UK, 2009; pp. 267-285. [CrossRef]

15. Gade, A.; Ingle, A.; Whiteley, C.; Rai, M. Mycogenic metal nanoparticles: Progress and applications. Biotechnol. Lett. 2010, 32, 593-600. [CrossRef] [PubMed]

16. Ahmad, A.; Mukherjee, P.; Senapati, S.; Mandal, D.; Khan, M.I.; Kumar, R.; Sastry, M. Extracellular biosynthesis of silver nanoparticles using the fungus Fusarium oxysporum. Coll. Surf. B Biointerfaces 2003, 28, 313-318. [CrossRef]

17. Bansal, V.; Rautaray, D.; Ahmad, A.; Sastry, M. Biosynthesis of zirconia nanoparticles using the fungus Fusarium oxysporum. J. Mater. Chem. 2004, 14, 3303-3305. [CrossRef]

18. Reyes, L.R.; Gómez, I.; Garza, M.T. Biosynthesis of cadmium sulfide nanoparticles by the fungi Fusarium sp. Int. J. Green Nanotechnol. Biomed. 2009, 1, B90-B95. [CrossRef]

19. Basavaraja, S.; Balaji, S.D.; Lagashetty, A.; Rajasab, A.H.; Venkataraman, A. Extracellular biosynthesis of silver nanoparticles using the fungus Fusarium semitectum. Mater. Res. Bull. 2008, 43, 1164-1170. [CrossRef]

20. Siddiqi, K.S.; Husen, A. Fabrication of metal nanoparticles from fungi and metal salts: Scope and application. Nanoscale Res. Lett. 2016, 11, 98. [CrossRef]

21. Khan, N.T.; Jameel, M.; Jameel, J. Silver nanoparticles biosynthesis by Fusarium oxysporum and determination of its antimicrobial potency. J. Nanomed. Biotherapeutic. Discov. 2017, 7, 1. [CrossRef]

22. Mahmoud, M.A.; Al-Sohaibani, S.A.; Al-Othman, M.R.; El-Aziz, A.M.A.; Eifan, S.A. Synthesis of extracellular silver nanoparticles using Fusarium semitectum (KSU-4) isolated from Saudi Arabia. Dig. J. Nanomat. Biostruct. 2013, 8, 589-596. [CrossRef]

23. Elamawi, R.M.; Al-Harbi, R.E.; Hendi, A.A. Biosynthesis and characterization of silver nanoparticles using Trichoderma longibrachiatum and their effect on phytopathogenic fungi. Egypt. J. Biol. Pest Control 2018, 28, 28. [CrossRef]

24. Noor, S.; Shah, Z.; Javed, A.; Ali, A.; Hussain, S.B.; Zafar, S.; Ali, H.; Muhammad, S.A. A fungal based synthesis method for copper nanoparticles with the determination of anticancer, antidiabetic and antibacterial activities. J. Microbiol. Methods 2020, 174, 105966. [CrossRef]

25. Lange, K.; Swift, P.G.F.; Pankowska, E.; Danne, T. Diabetes education in children and adolescents. Pediatric Diabetes 2014, 15, 77-85. [CrossRef]

26. Solomon, L.; Tomii, V. Dick Importance of fungi in the petroleum, agro-allied, agriculture and pharmaceutical industries. N. $Y$. Sci. J. 2019, 12, 5. [CrossRef]

27. Tidke, P.R.; Gupta, I.; Gade, A.K.; Rai, M. Fungus-mediated synthesis of gold nanoparticles and standardization of parameters for its biosynthesis. IEEE Trans. NanoBiosci. 2014, 13, 397-402. [CrossRef]

28. Bawaskar, M.; Gaikwad, S.; Ingle, A.; Rathod, D.; Gade, A.; Durán, N.; Marcato, P.D.; Rai, M. A New Report on mycosynthesis of silver nanoparticles by Fusarium culmorum. Curr. Nanosci. 2010, 6, 376-380. [CrossRef]

29. Khalil, N.M.; El-Ghany, M.N.A.; Rodríguez-Couto, S. Antifungal and anti-mycotoxin efficacy of biogenic silver nanoparticles produced by Fusarium chlamydosporum and Penicillium chrysogenum at non-cytotoxic doses. Chemosphere 2019, 218, $477-486$. [CrossRef] [PubMed]

30. Gaikwad, S.C.; Birla, S.S.; Ingle, A.P.; Gade, A.K.; Marcato, P.D.; Rai, M.K.; Durán, N. Screening of different Fusarium species to select potential species for the synthesis of silver nanoparticles. J. Braz. Chem. Soc. 2013, 24, 1974-1982. [CrossRef]

31. Mohamed, A.A.; Fouda, A.; Abdel-Rahman, M.A.; Hassan, S.E.-D.; El-Gamal, M.S.; Salem, S.S.; Shaheen, T.I. Fungal strain impacts the shape, bioactivity and multifunctional properties of green synthesized zinc oxide nanoparticles. Biocatal. Agric. Biotechnol. 2019, 19, 101103. [CrossRef]

32. Mohamed, A.A.; Fouda, A.; Elgamal, M.S.; Hassan, S.; Shaheen, T.I.; Salem, S.S. Enhancing of cotton fabric antibacterial properties by silver nanoparticles synthesized by new egyptian strain Fusarium keratoplasticum A1-3. In Egyptian Journal of Chemistry 60, Proceedings of the 8th International Conference of the Textile Research Division (ICTRD 2017), Cairo, Egypt, 25-27 September 2017; National Research Centre: Dokki, Egypt, 2017; pp. 63-71. [CrossRef]

33. Birla, S.S.; Gaikwad, S.C.; Gade, A.K.; Rai, M.K. Rapid Synthesis of silver nanoparticles from Fusarium oxysporum by optimizing physicocultural conditions. Sci. World J. 2013, 2013, 1-12. [CrossRef]

34. Bansod, S.; Bonde, S.; Tiwari, V.; Bawaskar, M.; Deshmukh, S.; Gaikwad, S.; Gade, A.; Rai, M. Bioconjugation of gold and silver nanoparticles synthesized by Fusarium oxysporum and their use in rapid identification of Candida species by using bioconjugatenano-polymerase chain reaction. J. Biomed. Nanotechnol. 2013, 9, 1962-1971. [CrossRef]

35. Sanyal, A.; Rautaray, D.; Bansal, V.; Ahmad, A.; Sastry, M. Heavy-metal remediation by a fungus as a means of production of lead and cadmium carbonate crystals. Langmuir 2005, 21, 7220-7224. [CrossRef]

36. Rautaray, D.; Sanyal, A.; Adyanthaya, S.D.; Ahmad, A.; Sastry, M. Biological synthesis of strontium carbonate crystals using the fungus Fusarium oxysporum. Langmuir 2004, 20, 6827-6833. [CrossRef]

37. Ahmad, A.; Mukherjee, P.; Mandal, D.; Senapati, S.; Khan, M.I.; Kumar, R.; Sastry, M. Enzyme mediated extracellular synthesis of CdS nanoparticles by the fungus, Fusarium oxysporum. J. Am. Chem. Soc. 2002, 124, 12108-12109. [CrossRef] [PubMed] 
38. Bansal, V.; Rautaray, D.; Bharde, A.; Ahire, K.; Sanyal, A.; Ahmad, A.; Sastry, M. Fungus-mediated biosynthesis of silica and titania particles. J. Mater. Chem. 2005, 15, 2583-2589. [CrossRef]

39. Bansal, V.; Poddar, P.; Ahmad, A.A.; Sastry, M. Room-temperature biosynthesis of ferroelectric barium titanate nanoparticles. J. Am. Chem. Soc. 2006, 128, 11958-11963. [CrossRef]

40. Bansal, V.; Sanyal, A.; Rautaray, D.; Ahmad, A.; Sastry, M. Bioleaching of sand by the fungus Fusarium oxysporum as a means of producing extracellular silica nanoparticles. Adv. Mater. 2005, 17, 889-892. [CrossRef]

41. Gupta, K.; Chundawat, T.S. Bio-inspired synthesis of platinum nanoparticles from fungus Fusarium oxysporum: Its characteristics, potential antimicrobial, antioxidant and photocatalytic activities. Mater. Res. Express 2019, 6, 1-10. [CrossRef]

42. Bharde, A.; Rautaray, D.; Bansal, V.; Ahmad, A.; Sarkar, I.; Yusuf, S.M.; Sanyal, M.; Sastry, M. Extracellular biosynthesis of magnetite using fungi. Small 2006, 2, 135-141. [CrossRef]

43. Kumar, S.; Kumar, D.; Dilbaghi, N. Preparation, characterization, and bio-efficacy evaluation of controlled release carbendazimloaded polymeric nanoparticles. Environ. Sci. Pollut. Res. 2017, 24, 926-937. [CrossRef]

44. Senapati, S.; Syed, A.; Khan, S.; Pasricha, R.; Khan, M.I.; Kumar, R.; Ahmad, A. Extracellular biosynthesis of metal sulfide nanoparticles using the fungus Fusarium oxysporum. Curr. Nanosci. 2014, 10, 588-595. [CrossRef]

45. Ganapathy, S.; Siva, K. Bio-synthesis, characterisation and application of titanium oxide nanoparticles by Fusarium oxysporum. Int. J. Life Sci. Res. 2016, 4, 69-75. [CrossRef]

46. Boruah, S.; Dutta, P. Fungus mediated biogenic synthesis and characterization of chitosan nanoparticles and its combine effect with Trichoderma asperellum against Fusarium oxysporum, Sclerotium rolfsii and Rhizoctonia solani. Indian Phytopathol. 2020, 1-13. [CrossRef]

47. Mirzadeh, S.; Darezereshki, E.; Bakhtiari, F.; Fazaelipoor, M.H.; Hosseini, M.R. Characterization of zinc sulfide (ZnS) nanoparticles biosynthesized by Fusarium oxysporum. Mater. Sci. Semiconduct. Process. 2013, 16, 374-378. [CrossRef]

48. Thakker, J.N.; Dalwadi, P.; Dhandhukia, P.C. Biosynthesis of gold nanoparticles using Fusarium oxysporum f. sp. cubense JT1, a plant pathogenic fungus. ISRN Biotechnol. 2013, 2013, 1-5. [CrossRef]

49. Rajput, S.; Werezuk, R.; Lange, R.M.; McDermott, M.T. Fungal isolate optimized for biogenesis of silver nanoparticles with enhanced colloidal stability. Langmuir 2016, 32, 8688-8697. [CrossRef]

50. Riddin, T.L.; Gericke, M.; Whiteley, C.G. Analysis of the inter- and extracellular formation of platinum nanoparticles by Fusarium oxysporum f. sp. lycopersiciusing response surface methodology. Nanotechnology 2006, 17, 3482-3489. [CrossRef] [PubMed]

51. Cárdenas, D.I.S.; Gomez-Ramirez, M.; Rojas-Avelizapa, N.G.; Vidales-Hurtado, M.A. Synthesis of cadmium sulfide nanoparticles by biomass of Fusarium oxysporum f. sp. lycopersici. J. Nano Res. 2017, 46, 179-191. [CrossRef]

52. Karbasian, M.; Atyabi, S.M.; Siadat, S.D.; Momen, S.B.; Norouzian, D. Optimizing nanosilver formation by Fusarium oxysporum PTCC 5115 employing response surface methodology. AJABS 2008, 3, 433-437. [CrossRef]

53. Ajah, A.H.; Hassan, A.S.; Aja, H.A. Extracellular biosynthesis of silver nanoparticles using Fusarium graminearum and their antimicrobial activity. J. Global Pharma Technol. 2018, 10, 683-689.

54. Rodríguez-Serrano, C.; Guzmán-Moreno, J.; Ángeles-Chávez, C.; Rodríguez-González, V.; Ortega-Sigala, J.J.; Ramírez-Santoyo, R.M.; Vidales-Rodríguez, L.E. Biosynthesis of silver nanoparticles by Fusarium scirpi and its potential as antimicrobial agent against uropathogenic Escherichia coli biofilms. PLoS ONE 2020, 15, e0230275. [CrossRef] [PubMed]

55. Sawle, B.D.; Salimath, B.; Deshpande, R.; Bedre, M.D.; Prabhakar, B.K.; Venkataraman, A. Biosynthesis and stabilization of Au and Au-Ag alloy nanoparticles by fungus, Fusarium semitectum. Sci. Technol. Adv. Mater. 2008, 9, 035012. [CrossRef]

56. Madakka, M.; Jayaraju, N.; Rajesh, N. Mycosynthesis of silver nanoparticles and their characterization. MethodsX 2018, 5, 20-29. [CrossRef]

57. Abbas, H.; Baker, D.A. Biological evaluation of selenium nanoparticles biosynthesized by Fusarium semitectum as antimicrobial and anticancer agents. Egypt. J. Chem. 2020, 4, 18-19. [CrossRef]

58. Mohammed, A.E.; Baz, F.F.B.; Albrahim, J.S. Calligonum comosum and Fusarium sp. extracts as bio-mediator in silver nanoparticles formation: Characterization, antioxidant and antibacterial capability. 3 Biotech 2018, 68, 72. [CrossRef] [PubMed]

59. Kavitha, N.S.; Venkatesh, K.S.; Palani, N.S.; Ilangovan, R. Synthesis and characterization of zirconium oxide nanoparticles using Fusarium solani extract. In Proceedings of the 64th DAE Solid State Physics Symposium, Mumbai, India, 18-22 December 2019; AIP Publishing LLC.: Melville, NY, USA, 2020; Volume 2265, p. 030057. [CrossRef]

60. Clarance, P.; Luvankar, B.; Sales, J.; Khusro, A.; Agastian, P.; Tack, J.-C.; Al Khulaifi, M.M.; Al-Shwaiman, H.A.; Elgorban, A.M.; Syed, A.; et al. Green synthesis and characterization of gold nanoparticles using endophytic fungi Fusarium solani and its in-vitro anticancer and biomedical applications. Saudi J. Biol. Sci. 2020, 27, 706-712. [CrossRef]

61. Mekkawy, A.I.; El-Mokhtar, M.A.; Nafady, N.A.; Yousef, N.; Hamad, M.A.; El-Shanawany, S.M.; Ibrahim, E.H.; Elsabahy, M. In vitro and in vivo evaluation of biologically synthesized silver nanoparticles for topical applications: Effect of surface coating and loading into hydrogels. Int. J. Nanomed. 2017, 12, 759-777. [CrossRef]

62. Gade, A.; Bonde, P.; Ingle, A.P.; Marcato, P.D.; Duran, N.; Rai, M. Exploitation of Aspergillus niger for synthesis of silver nanoparticles. J. Biobased Mater. Bioenergy 2008, 2, 243-247. [CrossRef]

63. Slavin, Y.N.; Asnis, J.; Häfeli, U.O.; Bach, H. Metal nanoparticles: Understanding the mechanisms behind antibacterial activity. J. Nanobiotechnol. 2017, 15, 65. [CrossRef]

64. Naimi-Shamel, N.; Pourali, P.; Dolatabadi, S. Green synthesis of gold nanoparticles using Fusarium oxysporum and antibacterial activity of its tetracycline conjugant. J. Mycologie Médicale 2019, 29, 7-13. [CrossRef] 
65. Pourali, P.; Yahyaei, B.; Afsharnezhad, S. Bio-synthesis of gold nanoparticles by Fusarium oxysporum and assessment of their conjugation possibility with two types of $\beta$-lactam antibiotics without any additional linkers. Microbiology 2018, 87, $229-237$. [CrossRef]

66. El Sayed, M.T.; El-Sayed, A.S.A. Biocidal Activity of Metal Nanoparticles Synthesized by Fusarium solani against MultidrugResistant Bacteria and Mycotoxigenic Fungi. J. Microbiol. Biotechnol. 2020, 30, 226-236. [CrossRef]

67. Srivastava, S.; Bhargava, A.; Pathak, N.; Srivastava, P. Production, characterization and antibacterial activity of silver nanoparticles produced by Fusarium oxysporum and monitoring of protein-ligand interaction through in-silico approaches. Microb. Pathog. 2019, 129, 136-145. [CrossRef]

68. Durán, N.; Marcato, P.D.; Alves, O.L.; De Souza, G.I.H.; Esposito, E. Mechanistic aspects of biosynthesis of silver nanoparticles by several Fusarium oxysporum strains. J. Nanobiotechnol. 2005, 3, 8. [CrossRef]

69. Kumar, S.A.; Abyaneh, M.K.; Gosavi, S.W.; Kulkarni, S.K.; Pasricha, R.; Ahmad, A.; Khan, M.I. Nitrate reductase-mediated synthesis of silver nanoparticles from $\mathrm{AgNO}_{3}$. Biotechnol. Lett. 2007, 29, 439-445. [CrossRef]

70. Fadeel, B.; Garcia-Bennett, A.E. Better safe than sorry: Understanding the toxicological properties of inorganic nanoparticles manufactured for biomedical applications. Adv. Drug Deliv. Rev. 2009, 62, 362-374. [CrossRef] [PubMed]

71. Tian, F.; Prina-Mello, A.; Estrada, G.; Beyerle, A.; Möller, W.; Schulz, H.; Kreyling, W.; Stoeger, T. A novel assay for the quantification of internalized nanoparticles in macrophages. Nanotoxicology 2008, 2, 232-242. [CrossRef]

72. Cui, D.; Tian, F.; Coyer, S.R.; Wang, J.; Pan, B.; Gao, F.; He, R.; Zhang, Y. Effects of antisense-myc-conjugated single-walled carbon nanotubes on HL-60Cells. J. Nanosci. Nanotechnol. 2007, 7, 1639-1646. [CrossRef] [PubMed]

73. Kowshik, M.; Ashtaputre, S.; Kharrazi, S.; Vogel, W.; Urban, J.; Kulkarni, S.K.; Paknikar, K.M. Extracellular synthesis of silver nanoparticles by a silver-tolerant yeast strain MKY3. Nanotechnol. 2003, 14, 95-100. [CrossRef]

74. Loo, Y.Y.; Rukayadi, Y.; Nor-Khaizura, M.R.; Kuan, C.H.; Chieng, B.W.; Nishibuchi, M.; Radu, M. In vitro antimicrobial activity of green synthesized silver nanoparticles against selected gram-negative foodborne pathogens. Front. Microbiol. $2018,9,1555$. [CrossRef]

75. Al-Askar, A.; Hafez, E.E.; Kabeil, S.A.; Meghad, A. Bioproduction of silver-nano particles by Fusarium oxysporum and their antimicrobial activity against some plant pathogenic bacteria and fungi. Life Sci. J. 2013, 10, 2470-2475.

76. Ishida, K.; Cipriano, T.F.; Rocha, G.M.; Weissmüller, G.; Gomes, F.; Miranda, K.; Rozental, S.; Cruz, M.; de Janeiro, R. Silver nanoparticle production by the fungus Fusarium oxysporum: Nanoparticle characterisation and analysis of antifungal activity against pathogenic yeasts. Mem. Inst. Oswaldo Cruz 2014, 109, 220-228. [CrossRef] [PubMed]

77. Elechiguerra, J.L.; Burt, J.L.; Morones, J.R.; Camacho-Bragado, A.; Gao, X.; Lara, H.H.; Yacaman, M.J. Interaction of silver nanoparticles with HIV-1. J. Nanobiotechnol. 2005, 3, 1-8. [CrossRef]

78. Akbarzadeh, A.; Kafshdooz, L.; Razban, Z.; Tbrizi, A.D.; Rasoulpour, S.; Khalilov, R.; Kavetskyy, T.; Saghfi, S.; Nasibova, A.N.; Kaamyabi, S.; et al. An overview application of silver nanoparticles in inhibition of herpes simplex virus. Artif. Cells Nanomed. Biotechnol. 2018, 46, 263-267. [CrossRef] [PubMed]

79. Husseiny, S.M.; Salah, T.A.; Anter, H.A. Biosynthesis of size controlled silver nanoparticles by Fusarium oxysporum, their antibacterial and antitumor activities. Beni Suef Univ. J. Basic Appl. Sci. 2015, 4, 225-231. [CrossRef]

80. Horky, P.; Skalickova, S.; Baholet, D.; Skladanka, J. Nanoparticles as a solution for eliminating the risk of mycotoxins. Nanomater. 2018, 8, 727. [CrossRef]

81. Sayed, A.M.M.; Kim, S.; Behle, R.W. Characterisation of silver nanoparticles synthesised by Bacillus thuringiensis as a nanobiopesticide for insect pest control. Biocontrol Sci. Technol. 2017, 27, 1308-1326. [CrossRef]

82. Dhanasekaran, D.; Thangaraj, R. Evaluation of larvicidal activity of biogenic nanoparticles against filariasis causing Culex mosquito vector. Asian Pac. J. Trop. Dis. 2013, 3, 174-179. [CrossRef]

83. Jo, Y.K.; Kim, B.H.; Jung, G. Antifungal activity of silver ions and nanoparticles on phytopathogenic fungi. Plant Dis. 2009, 93, 1037-1043. [CrossRef]

84. U.N. Department of Economic and Social Affairs. Population Division 2019, World Population Prospects; United Nations: New York, NY, USA, 2019.

85. Hietzschold, S.; Walter, A.; Davis, C.; Taylor, A.A.; Sepunaru, L. Does nitrate reductase play a role in silver nanoparticle synthesis? evidence for NADPH as the sole reducing agent. ACS Sustain. Chem. Eng. 2019, 7, 8070-8076. [CrossRef]

86. Partila, A.M. Bioproduction of silver nanoparticles and its potential applications in agriculture. In Nanotechnology for Agriculture; Panpatte, D.G., Jhala, Y.K., Eds.; Springer: Singapore, 2019. [CrossRef]

87. He, X.; Deng, H.; Hwang, H.-M. The current application of nanotechnology in food and agriculture. J. Food Drug Anal. 2019, 27, 1-21. [CrossRef] [PubMed]

88. Oliveira, H.C.; Stolf-Moreira, R.; Martinez, C.B.R.; Grillo, R.; De Jesus, M.B.; Fraceto, L.F.U. Nanoencapsulation enhances the post-emergence herbicidal activity of atrazine against mustard plants. PLoS ONE 2015, 10, e0132971. [CrossRef]

89. Cao, L.; Zhou, Z.; Niu, S.; Cao, C.; Li, X.; Shan, Y.; Huang, Q. Positive-charge functionalized mesoporous silica nanoparticles as nanocarriers for controlled 2,4-dichlorophenoxy acetic acid sodium salt release. J. Agric. Food Chem. 2018, 66, 6594-6603. [CrossRef]

90. Duhan, J.S.; Kumar, R.; Kumar, N.; Kaur, P.; Nehra, K.; Duhan, S. Nanotechnology: The new perspective in precision agriculture. Biotechnol. Rep. 2017, 15, 11-23. [CrossRef] [PubMed] 
91. Khot, L.R.; Sankaran, S.; Maja, J.M.; Ehsani, R.; Schuster, E.W. Applications of nanomaterials in agricultural production and crop protection: A review. Crop. Prot. 2012, 35, 64-70. [CrossRef]

92. Sekhon, B.S. Nanotechnology in agri-food production: An overview. Nanotechnol. Sci. Appl. 2014, 7, 31-53. [CrossRef] [PubMed]

93. Dimkpa, C.O.; McLean, J.E.; Britt, D.W.; Anderson, A.J. Antifungal activity of ZnO nanoparticles and their interactive effect with a biocontrol bacterium on growth antagonism of the plant pathogen Fusarium graminearum. BioMetals 2013, 26, 913-924. [CrossRef]

94. Rajiv, P.; Rajeshwari, S.; Venckatesh, R. Bio-Fabrication of zinc oxide nanoparticles using leaf extract of Parthenium hysterophorus L. and its size-dependent antifungal activity against plant fungal pathogens. Spectrochim. Acta Part A 2013, 112, 384-387. [CrossRef] [PubMed]

95. Bramhanwade, K.; Shende, S.; Bonde, S.; Gade, A.; Rai, M. Fungicidal activity of Cu nanoparticles against Fusarium causing crop diseases. Environ. Chem. Lett. 2016, 14, 229-235. [CrossRef]

96. Dimkpa, C.O.; Bindraban, P.S. Nanofertilizers: New Products for the industry? J. Agric. Food Chem. 2018, 66, 6462-6473. [CrossRef]

97. Tripathi, K.M.; Bhati, A.; Singh, A.; Sonker, A.K.; Sarkar, S.; Sonkar, S.K. Sustainable changes in the contents of metallic micronutrients in first generation gram seeds imposed by carbon nano-onions: Life cycle seed to seed study. ACS Sustain. Chem. Eng. 2017, 5, 2906-2916. [CrossRef]

98. Khalifa, N.S.; Hasaneen, M.N. The effect of chitosan-PMAA-NPK nanofertilizer on Pisum sativum plants. 3 Biotech 2018, 8, 193. [CrossRef]

99. Abdel-Aziz, H.M.M.; Hasaneen, M.N.A.; Omer, A.M. Nano chitosan-NPK fertilizer enhances the growth and productivity of wheat plants grown in sandy soil. Spanish J. Agri. Res. 2016, 14, e0902. [CrossRef]

100. Shende, S.; Rathod, D.; Gade, A.; Rai, M. Biogenic copper nanoparticles promote the growth of pigeon pea (Cajanus cajan L.). IET Nanobiotechnol. 2017, 11, 773-781. [CrossRef]

101. Abbacia, A.; Azzouz, N.; Bouznit, Y. A new copper doped montmorillonite modified carbon paste electrode for propineb detection. Appl. Clay Sci. 2014, 90, 130-134. [CrossRef]

102. Wibowo, K.; Sahdan, M.; Ramli, N.; Muslihati, A.; Rosni, N.; Tsen, V.; Saïm, H.; Ahmad, S.; Sari, Y.; Mansor, Z. Detection of Escherichia coli bacteria in wastewater by using graphene as a sensing material. In Journal of Physics: Conference Series, Proceedings of the 2017 International Seminar on Mathematics and Physics in Sciences and Technology (ISMAP 2017), Batu Pahat, Malaysia, 28-29 October 2017; IOP Publishing Ltd.: Bristol, UK, 2018; Volume 995, p. 012063. [CrossRef]

103. Deng, H.; Gao, Y.; Dasari, T.P.S.; Ray, P.C.; Yu, H. A facile 3D construct of graphene oxide embedded with silver nanoparticles and its potential application as water filter. J. Miss. Acad. Sci. 2016, 61, 190-197. Available online: https://www.researchgate.net/ publication/312115792 (accessed on 13 October 2020).

104. Esser, B.; Schnorr, J.M.; Swager, T.M. Selective detection of ethylene gas using carbon nanotube-based devices: Utility in determination of fruit ripeness. Angew. Chem. Int. Ed. 2012, 51, 5752-5756. [CrossRef]

105. Geszke-Moritz, M.; Clavier, G.; Lulek, J.; Schneider, R. Copper- or manganese-doped ZnS quantum dots as fluorescent probes for detecting folic acid in aqueous media. J. Lumin. 2012, 132, 987-991. [CrossRef]

106. Jokar, M.; Safaralizadeh, M.H.; Hadizadeh, F.; Rahmani, F.; Kalani, M.R. Design and evaluation of an apta-nano-sensor to detect acetamiprid in vitro and in silico. J. Biomol. Struct. Dyn. 2016, 34, 2505-2517. [CrossRef]

107. Lin, Y.W.; Huang, C.C.; Chang, H.T. Gold nanoparticle probes for the detection of mercury, lead and copper ions. Analyst 2011, 136, 863-871. [CrossRef] [PubMed]

108. Korbekandi, H.; Ashari, Z.; Iravani, S.; Abbasi, S. Optimization of biological synthesis of silver nanoparticles using Fusarium oxysporum. Iran. J. Pharm. Res. 2013, 12, 289-298. [CrossRef]

109. Hamedi, S.; Ghaseminezhad, M.; Shokrollahzadeh, S.; Shojaosadati, S.A. Controlled biosynthesis of silver nanoparticles using nitrate reductase enzyme induction of filamentous fungus and their antibacterial evaluation. Artif. Cells Nanomed. Biotechnol. 2017, 45, 1588-1596. [CrossRef]

110. Zhang, X.; He, X.; Wang, K.; Yang, X. Different active biomolecules involved in biosynthesis of gold nanoparticles by three fungus species. J. Biomed. Nanotechnol. 2011, 7, 245-254. [CrossRef]

111. Senapati, S.; Ahmad, A.; Khan, M.I.; Sastry, M.; Kumar, R. Extracellular biosynthesis of bimetallic Au-Ag alloy nanoparticles. Small 2005, 1, 517-520. [CrossRef]

112. Govender, Y.; Riddin, T.; Gericke, M.; Whiteley, C.G. Bioreduction of platinum salts into nanoparticles: A mechanistic perspective. Biotechnol. Lett. 2009, 31, 95-100. [CrossRef]

113. Velmurugan, P.; Shim, J.; You, Y.; Choi, S.; Kamala-Kannan, S.; Lee, K.J.; Kim, H.J.; Oh, B.T. Removal of zinc by live, dead, and dried biomass of Fusarium spp. isolated from the abandoned-metal mine in South Korea and its perspective of producing nanocrystals. J. Hazard. Mater. 2010, 182, 317-324. [CrossRef]

114. Camargo, P.H.C.; Satyanarayana, K.G.; Wypych, F. Nanocomposites: Synthesis, structure, properties and new application opportunities. Mater. Res. 2009, 12,1-39. [CrossRef]

115. Hamzeh, M.; Sunahara, G.I. In vitro cytotoxicity and genotoxicity studies of titanium dioxide $\left(\mathrm{TiO}_{2}\right)$ nanoparticles in $\mathrm{Chinese}$ hamster lung fibroblast cells. Toxicol. Vitro 2013, 27, 864-873. [CrossRef] [PubMed]

116. Yu, S.J.; Yin, Y.G.; Liu, J.F. Silver nanoparticles in the environment. Environ. Sci. Process. Impacts 2013, 15, 78-92. [CrossRef] [PubMed]

117. Naidu, K.S.B.; Adam, J.K.; Govender, P. Biomedical applications and toxicity of nanosilver: A review. Med Technol. SA 2015, 29, 13-19. [CrossRef] 
118. Akter, M.; Sikder, T.; Rahman, M.; Ullah, A.A.; Hossain, K.F.B.; Banik, S.; Hosokawa, T.; Saito, T.; Kurasaki, M. A systematic review on silver nanoparticles-induced cytotoxicity: Physicochemical properties and perspectives. J. Adv. Res. 2018, 9, 1-16. [CrossRef]

119. Salaheldin, T.A.; Husseiny, S.M.; Al-Enizi, A.M.; Elzatahry, A.; Cowley, A.H. Evaluation of the Cytotoxic Behavior of Fungal extracellular synthesized Ag nanoparticles using confocal laser scanning microscope. Int. J. Mol. Sci. 2016, 17, 329. [CrossRef]

120. Akhtar, M.S.; Panwar, J.; Yun, Y.-S. Biogenic synthesis of metallic nanoparticles by plant extracts. ACS Sustain. Chem. Eng. 2013, 1, 591-602. [CrossRef]

121. Karatoprak, G.Ş.; Aydin, G.; Altinsoy, B.; Altinkaynak, C.; Koşar, M.; Ocsoy, I. The Effect of Pelargonium endlicherianum Fenzl. root extracts on formation of nanoparticles and their antimicrobial activities. Enzyme Microb. Technol. 2017, 97, 21-26. [CrossRef]

122. Siddiqi, K.S.; Husen, A.; Rao, R.A.K. A review on biosynthesis of silver nanoparticles and their biocidal properties. J. Nanobiotechnol. 2018, 16, 14. [CrossRef] [PubMed]

123. Barbalinardo, M.; Caicci, F.; Cavallini, M.; Gentili, D. Protein corona mediated uptake and cytotoxicity of silver nanoparticles in mouse embryonic fibroblast. Small 2018, 14, e1801219. [CrossRef]

124. Ritz, S.; Schöttler, S.; Kotman, N.; Baier, G.; Musyanovych, A.; Kuharev, J.; Landfester, K.; Schild, H.; Jahn, O.; Tenzer, S.; et al. Protein corona of nanoparticles: Distinct proteins regulate the cellular uptake. Biomacromolecules 2015, 16, 1311-1321. [CrossRef]

125. Nguyen, V.H.; Lee, B.J. Protein corona: A new approach for nanomedicine design. Int. J. Nanomed. 2017, 12, 3137-3151. [CrossRef] [PubMed]

126. Abbaszadegan, A.; Ghahramani, Y.; Gholami, A.; Hemmateenejad, B.; Dorostkar, S.; Nabavizadeh, M.; Sharghi, H. The effect of charge at the surface of silver nanoparticles on antimicrobial activity against Gram-positive and Gram-negative bacteria: A preliminary study. J. Nanomater. 2015, 2015, 1-8. [CrossRef]

127. Asharani, P.V.; Hande, M.P.; Valiyaveettil, S. Anti-proliferative activity of silver nanoparticles. BMC Cell Biol. 2009, 10, 65. [CrossRef] [PubMed]

128. Walczyk, D.; Bombelli, F.B.; Monopoli, M.P.; Lynch, I.; Dawson, K.A. What the Cell "Sees" in Bionanoscience. J. Am. Chem. Soc. 2010, 132, 5761-5768. [CrossRef] [PubMed]

129. Monopoli, M.P.; Åberg, C.; Salvati, A.; Dawson, K.A. Biomolecular coronas provide the biological identity of nanosized materials. Nat. Nanotechnol. 2012, 7, 779-786. [CrossRef]

130. Lee, Y.K.; Choi, E.-J.; Webster, T.J.; Kim, S.-H.; Khang, D. Effect of the protein corona on nanoparticles for modulating cytotoxicity and immunotoxicity. Int. J. Nanomed. 2014, 10, 97-113. [CrossRef]

131. Lesniak, A.; Fenaroli, F.; Monopoli, M.P.; Åberg, C.; Dawson, K.A.; Salvati, A. Effects of the presence or absence of a protein corona on silica nanoparticle uptake and impact on cells. ACS Nano 2012, 6, 5845-5857. [CrossRef] [PubMed]

132. Yilma, A.N.; Singh, S.R.; Dixit, S.; Dennis, V.A. Anti-inflammatory effects of silver-polyvinyl pyrrolidone (Ag-PVP) nanoparticles in mouse macrophages infected with live Chlamydia trachomatis. Int. J. Nanomed. 2013, 8, 2421-2432. [CrossRef]

133. Yin, N.; Liu, Q.; Liu, J.; He, B.; Cui, L.; Li, Z.; Yun, Z.; Qu, G.; Liu, S.; Zhou, Q.; et al. Silver nanoparticle exposure attenuates the viability of rat cerebellum granule cells through apoptosis coupled to oxidative stress. Small 2013, 9, 1831-1841. [CrossRef] [PubMed]

134. Braydich-Stolle, L.; Hussain, S.; Schlager, J.J.; Hofmann, M.C. In vitro cytotoxicity of nanoparticles in mammalian germline stem cells. Toxicol. Sci. 2005, 88, 412-419. [CrossRef]

135. Navya, P.N.; Daima, H.K. Rational engineering of physicochemical properties of nanomaterials for biomedical applications with nanotoxicological perspectives. Nano Converg. 2016, 3, 1-14. [CrossRef]

136. Soleimani, F.F.; Saleh, T.; Shojaosadati, S.A.; Poursalehi, R. Green synthesis of different shapes of silver nanostructures and evaluation of their antibacterial and cytotoxic activity. BioNanoScience 2018, 8, 72-80. [CrossRef]

137. Aueviriyavit, S.; Phummiratch, D.; Maniratanachote, R. Mechanistic study on the biological effects of silver and gold nanoparticles in Caco-2 cells-Induction of the Nrf2/HO-1 pathway by high concentrations of silver nanoparticles. Toxicol. Lett. 2014, 224, 73-83. [CrossRef]

138. Benn, T.; Cavanagh, B.; Hristovski, K.; Posner, J.D.; Westerhoff, P. The release of nanosilver from consumer products used in the home. J. Environ. Qual. 2010, 39, 1875-1882. [CrossRef]

139. Nel, A.; Xia, T.; Mädler, L.; Li, N. Toxic potential of materials at the nanolevel. Science 2006, 311, 622-627. [CrossRef]

140. Mishra, A.R.; Zheng, J.; Tang, X.; Goering, P.L. Silver nanoparticle-induced autophagic-lysosomal disruption and NLRP3inflammasome activation in HepG2 cells is size-dependent. Toxicol. Sci. 2016, 150, 473-487. [CrossRef] [PubMed]

141. Chen, X.; Schluesener, H.J. Nanosilver: A nanoproduct in medical application. Toxicol. Lett. 2008, 176, 1-12. [CrossRef] [PubMed]

142. Simon-Deckers, A.; Gouget, B.; Mayne-L'Hermite, M.; Herlin-Boime, N.; Reynaud, C.; Carrière, M. In vitro investigation of oxide nanoparticle and carbon nanotube toxicity and intracellular accumulation in A549 human pneumocytes. Toxicol. 2008, 253, 137-146. [CrossRef]

143. Xiu, Z.M.; Zhang, Q.B.; Puppala, H.L.; Colvin, V.L.; Alvarez, P.J. Negligible particle-specific antibacterial activity of silver nanoparticles. Nano Lett. 2012, 12, 4271-4275. [CrossRef]

144. Chernousova, S.; Epple, M. Silver as antibacterial agent: Ion, nanoparticle, and metal. Angew. Chem. Int. Ed. 2013, 52, 1636-1653. [CrossRef] [PubMed]

145. Cho, J.G.; Kim, K.T.; Ryu, T.K.; Lee, J.W.; Kim, J.E.; Kim, J.; Lee, B.C.; Jo, E.H.; Yoon, J.; Eom, I.C.; et al. Stepwise embryonic toxicity of silver nanoparticles on Oryzias latipes. BioMed Res. Int. 2013, 2013, 1-7. [CrossRef] 
146. Gorth, D.J.; Rand, D.M.; Webster, T.J. Silver nanoparticle toxicity in Drosophila: Size does matter. Int. J. Nanomed. 2011, 6, 343-350. [CrossRef]

147. Kruszewski, M.; Brzoska, K.; Brunborg, G.; Asare, N.; Dobrzyńska, M.; Dušinská, M.; Fjellsbø, L.M.; Georgantzopoulou, A.; Gromadzka-Ostrowska, J.; Gutleb, A.C.; et al. Toxicity of silver nanomaterials in higher eukaryotes. In Advances in Molecular Toxicology; Fishbein, J.C., Ed.; Elsevier: Amsterdam, The Netherlands, 2011; Volume 5, pp. 179-218.

148. Van Der Zande, M.; Vandebriel, R.J.; Van Doren, E.; Kramer, E.; Rivera, Z.H.; Serrano-Rojero, C.S.; Gremmer, E.R.; Mast, J.; Peters, R.J.B.; Hollman, P.C.H.; et al. Distribution, elimination, and toxicity of silver nanoparticles and silver ions in rats after 28-Day oral exposure. ACS Nano 2012, 6, 7427-7442. [CrossRef] [PubMed]

149. Sambale, F.; Wagner, S.; Stahl, F.; Khaydarov, R.R.; Scheper, T.; Bahnemann, D.W. Investigations of the toxic effect of silver nanoparticles on mammalian cell lines. J. Nanomater. 2015, 2015, 1-9. [CrossRef]

150. El Badawy, A.M.; Silva, R.G.; Morris, B.; Scheckel, K.G.; Suidan, M.T.; Tolaymat, T.M. Surface charge-dependent toxicity of silver nanoparticles. Environ. Sci. Technol. 2011, 45, 283-287. [CrossRef]

151. Joshi, N.; Ngwenya, B.T.; French, C.E. Enhanced resistance to nanoparticle toxicity is conferred by overproduction of extracellular polymeric substances. J. Hazard. Mater. 2012, 241, 363-370. [CrossRef] [PubMed]

152. Khan, S.S.; Mukherjee, A.; Chandrasekaran, N. Studies on interaction of colloidal silver nanoparticles (SNPs) with five different bacterial species. Coll. Surf. B Biointerfaces 2011, 87, 129-138. [CrossRef]

153. Khan, S.S.; Srivatsan, P.; Vaishnavi, N.; Mukherjee, A.; Chandrasekaran, N. Interaction of silver nanoparticles (SNPs) with bacterial extracellular proteins (ECPs) and its adsorption isotherms and kinetics. J. Hazard. Mater. 2011, 192, 299-306. [CrossRef]

154. Baruwati, B.; Simmons, S.O.; Varma, R.S.; Veronesi, B. “Green” synthesized and coated nanosilver alters the membrane permeability of barrier (intestinal, brain endothelial) cells and stimulates oxidative stress pathways in neurons. ACS Sustain. Chem. Eng. 2013, 1, 753-759. [CrossRef]

155. Ferreira, L.A.; Dos Reis, S.B.; da Silva, E.D.N.; Cadore, S.; da Silva Bernardes, J.; Durán, N.; de Jesus, M.B. Thiol-antioxidants interfere with assessing silver nanoparticle cytotoxicity. Nanomed. Nanotechnol. Biol. Med. 2020, 24, 102130. [CrossRef] [PubMed]

156. Marcato, P.D.; Nakasato, G.; Brocchi, M.; Melo, P.S.; Huber, S.C.; Ferreira, I.R.; Alves, O.L.; Durán, N. Biogenic Silver Nanoparticles: Antibacterial and cytotoxicity applied to textile fabrics. J. Nano Res. 2012, 20, 69-76. [CrossRef]

157. Vijayan, S.; Divya, K.; George, T.K.; Jisha, M.S. Biogenic synthesis of silver nanoparticles using endophytic fungi Fusarium oxysporum isolated from Withania somnifera (L.), its antibacterial and cytotoxic activity. J. Bionanosci. 2016, 10, 369-376. [CrossRef]

158. Asharani, P.V.; Mun, G.L.K.; Hande, M.P.; Valiyaveettil, S. Cytotoxicity and genotoxicity of silver nanoparticles in human cells. ACS Nano 2009, 3, 279-290. [CrossRef] [PubMed]

159. Gurunathan, S.; Park, J.H.; Han, J.W.; Kim, J.H. Comparative assessment of the apoptotic potential of silver nanoparticles synthesized by Bacillus tequilensis and Calocybe indica in MDA-MB-231 human breast cancer cells: Targeting p53 for anticancer therapy. Int. J. Nanomed. 2015, 10, 4203-4223. [CrossRef]

160. Supino, R. MTT Assays: In Vitro Toxicity Testing Protocols. In Methods in Molecular Biology; O'Hare, S., Atterwill, C.K., Eds.; Humana Press: Totowa, NJ, USA, 1995; Volume 43.

161. Pourali, P.; Badiee, S.H.; Manafi, S.; Noorani, T.; Rezaei, A.; Yahyaei, B. Biosynthesis of gold nanoparticles by two bacterial and fungal strains, Bacillus cereus and Fusarium oxysporum, and assessment and comparison of their nanotoxicity in vitro by direct and indirect assays. Electron. J. Biotechnol. 2017, 29, 86-93. [CrossRef]

162. Andersson, L.O. Study of some silver-thiol complexes and polymers: Stoichiometry and optical effects. J. Polym. Sci. Part A-1 Polym. Chem. 1972, 10, 1963-1973. [CrossRef]

163. Li, X.; Lenhart, J.J. Aggregation and dissolution of silver nanoparticles in natural surface water. Environ. Sci. Technol. 2012, 46, 5378-5386. [CrossRef]

164. Almofti, M.R.; Ichikawa, T.; Yamashita, K.; Terada, H.; Shinohara, Y. Silver ion induces a cyclosporine a-insensitive permeability transition in rat liver mitochondria and release of apoptogenic cytochrome c. J. Biochem. 2003, 134, 43-49. [CrossRef]

165. Manivasagan, P.; Oh, J. Production of a novel fucoidanase for the green synthesis of gold nanoparticles by Streptomyces sp. and its cytotoxic effect on HeLa Cells. Mar. Drugs 2015, 13, 6818-6837. [CrossRef]

166. Park, H.Y.; Park, S.H.; Kim, G.Y.; Choi, I.W.; Kim, S.; Kim, H.S.; Cha, H.J.; Choi, Y.H.; Jeong, J.W.; Yoon, D.; et al. Induction of p53-independent apoptosis and G1 cell cycle arrest by fucoidan in HCT116 human colorectal carcinoma cells. Mar. Drugs 2017, 15, 154-159. [CrossRef] [PubMed]

167. Hamzah, H.M.; Salah, R.F.; Maroof, M.N. Fusarium mangiferae as new cell factories for producing silver nanoparticles. J. Microbiol. Biotechnol. 2018, 28, 1654-1663. [CrossRef]

168. Al-Sharqi, S.A.H. Histological and biometric study of the effects of Fusarium graminarum silver nanoparticles on the kidney in male albino mice. Med. Leg. Update 2020, 20, 1028-1035. [CrossRef] 